NBER WORKING PAPER SERIES

\title{
THE EVOLUTION OF CULTURE AND INSTITUTIONS: EVIDENCE FROM THE KUBA KINGDOM
}

\author{
Sara Lowes \\ Nathan Nunn \\ James A. Robinson \\ Jonathan Weigel \\ Working Paper 21798 \\ http://www.nber.org/papers/w21798 \\ NATIONAL BUREAU OF ECONOMIC RESEARCH \\ 1050 Massachusetts Avenue \\ Cambridge, MA 02138 \\ December 2015
}

A number of individuals provided valuable help during the project. We thank Anne Degrave, James Diderich, Muana Kasongo, Eduardo Montero, Roger Makombo, Jim Mukenge, Eva Ng, Matthew Summers, Adam Xu, and Jonathan Yantzi. For comments, we thank Ran Abramitzky, Chris Blattman, Jean Ensminger, James Fenske, Raquel Fernandez, Carolina Ferrerosa-Young, Avner Greif, Joseph Henrich, Karla Hoff, Christine Kenneally, Alexey Makarin, Anselm Rink, Noam Yuchtman, as well as participants at numerous conferences and seminars. We gratefully acknowledge funding from the Pershing Square Venture Fund for Research on the Foundations of Human Behavior and the National Science Foundation (NSF). The views expressed herein are those of the authors and do not necessarily reflect the views of the National Bureau of Economic Research.

NBER working papers are circulated for discussion and comment purposes. They have not been peerreviewed or been subject to the review by the NBER Board of Directors that accompanies official NBER publications.

(C) 2015 by Sara Lowes, Nathan Nunn, James A. Robinson, and Jonathan Weigel. All rights reserved. Short sections of text, not to exceed two paragraphs, may be quoted without explicit permission provided that full credit, including $(\odot)$ notice, is given to the source. 
The Evolution of Culture and Institutions: Evidence from the Kuba Kingdom

Sara Lowes, Nathan Nunn, James A. Robinson, and Jonathan Weigel

NBER Working Paper No. 21798

December 2015

JEL No. D03,N47

\section{ABSTRACT}

We use variation in historical state centralization to examine the impact of institutions on cultural norms. The Kuba Kingdom, established in Central Africa in the early 17th century by King Shyaam, had more developed state institutions than the other independent villages and chieftaincies in the region. It had an unwritten constitution, separation of political powers, a judicial system with courts and juries, a police force and military, taxation, and significant public goods provision. Comparing individuals from the Kuba Kingdom to those from just outside the Kingdom, we find that centralized formal institutions are associated with weaker norms of rule-following and a greater propensity to cheat for material gain.

Sara Lowes

Department of Economics

Harvard University

1805 Cambridge Street

Cambridge, MA

02138

slowes@fas.harvard.edu

Nathan Nunn

Department of Economics

Harvard University

1805 Cambridge $\mathrm{St}$

Cambridge, MA 02138

and NBER

nnunn@fas.harvard.edu
James A. Robinson

University of Chicago

Harris School of Public Policy

1155 East 60th Street

Chicago, Illinois 60637

and NBER

jamesrobinson@uchicago.edu

Jonathan Weigel

Department of Government

Harvard University

1737 Cambridge Street

Cambridge, MA

02138

jweigel@fas.harvard.edu

Supplementary materials available at http://www.nber.org/papers/w21798:

- data appendix 


\section{Introduction}

Increasing evidence suggests that both culture and institutions are important for economic development. ${ }^{1}$ Institutions are typically defined as the external 'rules of the game' that shape individuals' expected material payoffs for different actions. Culture, by contrast, is often defined as the collection of internal values and beliefs of individuals in a society. While culture and institutions are typically treated as separate, it is plausible that they interact. In this paper we consider the effects that institutions have on culture. There are a number of plausible ways that institutions may affect cultural traits. It is possible that institutions that incentivize people to take particular actions may also generate cultural norms that lead individuals to want to choose these same actions. For example, institutions could incentivize patterns of behavior that over time come to be viewed as the 'right' behaviors, causing individuals to experience disutility when they deviate from them. In this case, institutions inculcate cultural norms that further reinforce the institutions themselves.

A number of scholars have argued for such complementary between institutions and culture. For example, sociologist Norbert Elias (1994) argues that in early modern Europe, a "civilizing process" took place that represented a "psychological change in the course of civilization". During this process a "more complex and stable control of conduct is increasingly instilled in the individual from his or her earlier years as an automatism, a self-compulsion that he or she cannot resist even if he or she consciously wishes to" (Elias, 1994, p. 367). According to Elias, this change in behavior was driven by state formation, which induced people to internalize rule-abiding behavior, a cultural complement to the underlying institutions. ${ }^{2}$ A related argument was also put forth by Eugene Weber (1976), who argued that the formation of the French state in the 19th century transformed France's diverse population into a citizenry socialized to obey the rules, and in particular, to pay taxes and to serve in the military. Finally, similar ideas were extensively developed by Michel Foucault (1995), who argued that modern society had moved from a situation where people obey the law because they fear punishment to one characterized by "disciplinary power" whereby individuals obey because they absorb the laws as their internal

\footnotetext{
${ }^{1}$ For evidence of the importance of institutions for economic development see e.g., North and Thomas (1973), Acemoglu, Johnson and Robinson (2001), and Acemoglu and Robinson (2012). For evidence on the importance of culture see e.g., Greif (1994), Tabellini (2008a), Tabellini (2010), and Algan and Cahuc (2010).

${ }^{2}$ Elias writes that the "peculiar stability of the psychological self-restraint which emerges as a decisive trait built into the habits of every civilized human being, stands in the closest relationship to the monopolization of physical force and the growing stability of the central organs of society" (Elias, 1994, p. 369).
} 
norms. Individuals are unwittingly disciplined to accept as "normal" what the state and the other disciplinary institutions deem as normal. Foucault describes this as a process of "normalization."

An alternative hypothesis is that the institutions associated with state formation undermine norms of rule-following and of engaging in socially desirable behavior more generally. This scenario is illustrated by Tabellini (2008b), who models parents' decisions to instill cooperative values in their children. When institutions are effective at punishing undesirable behavior, parents know that their children will be incentivized to cooperate. Since, in the model, parents only care about the actions of their children, and not their motivations, better enforcement of the rules i.e., better institutions - causes parents to invest less in cultivating an intrinsic desire to cooperate in their children. Here, formal institutions crowd out internal motivations. ${ }^{3}$

In this paper, we empirically test the impact of state formation on individuals' propensity to follow rules and obey laws. Our analysis exploits a unique historical episode in Central Africa: the creation of the Kuba Kingdom in the 17th century. A number of characteristics of the formation of the Kingdom make this historical episode particularly well-suited for examining our relationship of interest. First, during the medieval period, about two centuries prior to the formation of the Kingdom, there was a large migration of related Mongo peoples to an area near the confluence of the Kasai and Sankuru rivers. This migration is shown in figure 1, along with the boundaries of the Kuba Kingdom some two centuries later. These groups, according to oral histories, are descendants of a mythical ancestor named Woot. One implication of this migration is that, prior to the formation of the Kingdom, societies in the region were culturally similar, a homogeneous group of peoples who had recently migrated from the Northwest. The common origins of the peoples inhabiting the study region help alleviate concerns of reverse causality, namely that initial cultural differences caused the formation of the Kuba Kingdom.

The second significant aspect of the historical episode is the idiosyncratic manner in which the Kingdom was established. The Kingdom was formed when Shyaam, an institutional entrepreneur and an outsider, united a group of villages and small chieftaincies under the rule of the Bushong

\footnotetext{
3 Benabou and Tirole (2003) have a seminal model that also shows how extrinsic rewards can crowd-out intrinsic motivations. Their setting and mechanism is very different from that in Tabellini (20o8b). In their principal-agent framework, the crowding-out effect arises because the rewards offered by the principal provides information to the agent about her intrinsic ability which then affects her decisions.
} 
(Vansina, 1978, p. 127). ${ }^{4}$

Third, geographical features of the area had a decisive impact in determining the boundaries of the Kuba Kingdom. As shown in figure 1, the region where the "children of Woot" settled is naturally divided by the Kasai and Sankuru rivers. Shyaam established the Kingdom to the south of the Sankuru and to the east of the Kasai. During his reign and those of subsequent kings, the Kingdom expanded to the natural limits defined by these rivers. The boundaries of the Kuba Kingdom remained stable and clearly defined by the Kasai river (to the west), Sankuru river (to the north), and Lulua river (to the south). Although the specific location of these natural boundaries was otherwise unimportant, the rivers determined which villages were inside and outside of the Kuba Kingdom. We therefore argue that the establishment of the Kingdom to the east of the Kasai, rather than to the west, occurred for idiosyncratic reasons, not because of pre-existing differences in the populations or the enviroment.

Finally, the Kuba Kingdom had many characteristics that are associated with modern states, making the estimated effects of the Kuba state on cultural norms of general interest. The Kingdom had a capital city where the king and members of numerous executive councils lived. Additionally, it had a professional bureaucracy, an unwritten constitution, a sophisticated legal system that featured trial by jury and courts of appeal, a professional police force, a military, a system of taxation, and extensive public goods provision.

The causal impact of state formation depends on the nature of the state being considered relative to the absence of a state. ${ }^{5}$ It is possible that 'predatory' or 'authoritarian' states, which lack legitimacy, might have very different impacts on rule-following than democratic or legitimate states. ${ }^{6}$ Thus, the fact that the Kuba state approximated a legitimate bureaucratized state with the rule of law makes it an attractive context in which to study the hypotheses of interest.

In sum, the idiosyncratic origins of the Kuba Kingdom, amidst the culturally homogeneous Mongo peoples, provides a compelling natural experiment that we use to estimate the impact of

\footnotetext{
4In many ways it is remarkable that an outsider was able to create a large centralized state in what oral histories describe as a peaceful process. The next section considers a number of explanations for Shyaam's ability to unify the Kingdom peacefully, which mirror a broader literature on the historical prevalence of "stranger kings" (e.g., de Heusch, 1982, Sahlins, 2008).

${ }^{5}$ There is no consensus in the social science literature on the taxonomy of different types of states. The recent empirical literature discusses the extent of state capacity, tending to associate it with the ability to raise taxes and impose effective regulation (Besley and Persson, 2011). Other scholars have tried to measure the extent of bureaucratization (Evans and Rauch, 2000) or centralization of authority (Dincecco, 2011).

${ }^{6}$ For example, some hypothesize that the Soviet state created a culture (known as 'blat') of illegality and informalism designed to circumvent the rules (Ledeneva, 2006).
} 


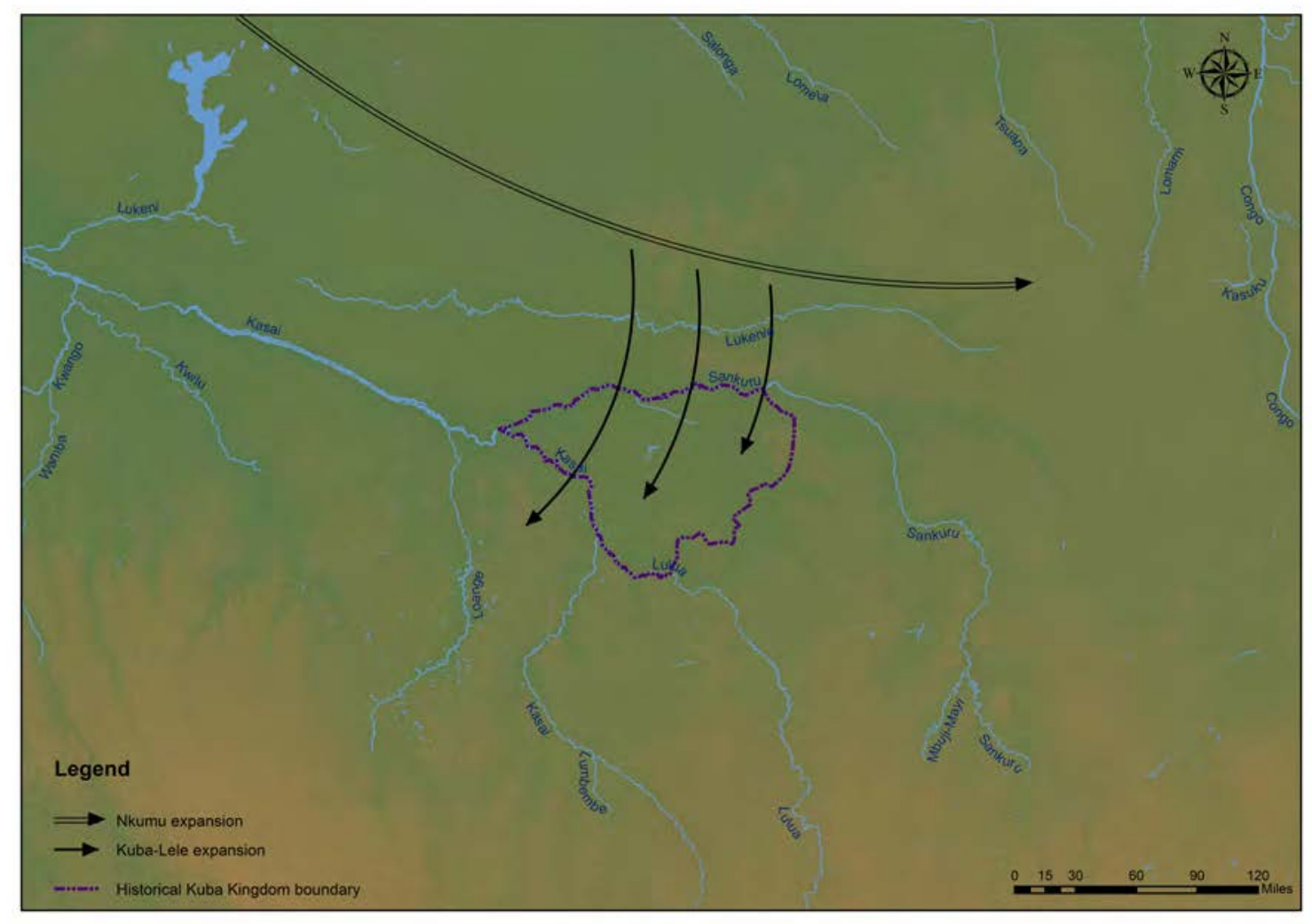

Figure 1: Historical migrations of the descendants of Woot and the formation of the Kuba Kingdom.

state formation on rule-following. While the villages on the Kuba side of the rivers that formed the Kingdom's boundaries were unified into a centralized state, the villages on the other side of these rivers continued to exist in small chieftaincies. ${ }^{7}$

Our empirical analysis estimates the effect of originating from the Kuba Kingdom on the propensity of individuals to obey rules even when there is a strong monetary incentive not to do so. We use two sets of behavioral experiments. The first is the resource allocation game (RAG). In the experiment, there is a cost to following the rules and a benefit to cheating. Although it is impossible for us or anyone else to know if any specific individual cheats, we are able to measure whether groups of individuals cheat by observing the frequency of outcomes in a larger sample. ${ }^{8}$ The second experiment is a version of the standard ultimatum game, in which

\footnotetext{
7Previous scholars have also identified this event as a near natural experiment, and have tended to focus their analysis on comparisons of the Kuba with the societies on the other side (i.e., west side) of the Kasai River, namely the Lele ethnic group. The differences between the Kuba Kingdom and the Lele (observed in the early and mid 2oth century) are documented in a series of publications by historian Jan Vansina (1963, 1964, 1978, 1990, 2010) and anthropologist Mary Douglas (1962, 1963).

${ }^{8}$ The experiment was developed by Hruschka, Efferson, Jiang, Falletta-Cowden, Sigurdsson, McNamara, Sands, Munira, Slingerland and Henrich (2014).
} 
participants physically allocate money in a private setting (rather than play on a computer). This provides an opportunity for individuals to steal money during the course of the experiment.

Our analysis compares individuals whose ancestors lived within the Kuba Kingdom to individuals whose ancestors lived just outside the Kingdom. The sample is taken from the local provincial capital, Kananga, the largest city in the region. Thus, individuals in our sample no longer live in their ancestral villages. They or their ancestors migrated to the provincial capital. Examining this population has several benefits. First, it is logistically easier to work in one city, rather than a number of villages in a region in which the transportation and communication infrastructure is extremely poor. Second, by considering a population of immigrants removed from the institutional environments of interest, we are better able to estimate the impact of these institutions on cultural norms. ${ }^{9}$

Our analysis examines three samples of interest. The first is the largest and includes all individuals whose ancestors lived inside and just outside the Kuba Kingdom. The second sample exploits the particular history of the region by including only the descendants of Woot, the population that was culturally homogeneous prior to the creation of the Kuba Kingdom. The descendants of Woot who remained outside the Kuba Kingdom are today called the Lele. Therefore, our second analysis compares the central Kuba (the Children of Woot who were inside the Kuba Kingdom) to the Lele. This is the cleanest comparison, as it exploits the cultural regression-discontinuity that arises due to the historical natural experiment described above. The third sample focuses specifically on the core peoples of the Kuba Kingdom, the Bushong, and compares them to the Lele. This comparison has two motivations. The first is the existing anthropological literature, which has focused on comparisons of the Bushong and Lele (e.g., Douglas, 1962, 1963, Vansina, 1963, 1964, 1978, 1990, 2010). Second, focusing on the Bushong helps address the issue of whether the Kuba institutions were viewed as legitimate by its citizens. The Bushong lived in the heart of the Kingdom and were disproportionately represented in the capital city and the government bureaucracy. Thus, the Bushong, of all groups, were most likely to view Kuba institutions as legitimate. ${ }^{10}$

According to our experimental measures of rule-following, a consistent and robust set of

9The strategy of examining immigrants from different cultural backgrounds but in the same current environment has been widely used in the cultural economics literature (e.g., Giuliano, 2007, Fernandez and Fogli, 2009, Alesina, Giuliano and Nunn, 2013).

10 The full sample has 499 individuals, 80 of which are Kuba. Of these, 62 individuals are central Kuba, including 38 Bushong. The sample also includes 45 Lele. 
empirical results emerge. We find that Kuba ancestry is associated with more rule breaking, more theft, and more cheating. This is true for both experiments and for all three samples of interest, most notably when we compare the central Kuba to the Lele and the Bushong to the Lele. These findings demonstrate that culture can be shaped by state institutions. They also show that culture and state institutions are not necessarily complements, as hypothesized by Elias, Weber, and Foucault. Instead, our findings are more consistent with other mechanisms, including those suggested in the model of Tabellini (2008b). Our findings are consistent with Kuba state crowding out internal norms of rule-following.

The difference between the conclusion of our analysis and that of the historical studies of Elias, Weber, and Foucault highlights an important methodological point. Observational studies like theirs infer underlying cultural norms based on observed actions, or in other words, equilibrium outcomes. However, the outcomes observed by Elias, Weber, and Foucault were surely influenced by the institutional environments in which they occurred; they are therefore unreliable measures of cultural norms. Our study attempts to sidestep this pitfall (i) by studying a population removed from the original institutional environments of interest, and (ii) by using experiments to directly measure individuals' propensity to follow rules and obey laws (in the absence of enforcement).

With the same methodology as Elias, Weber, and Foucault, one would also likely conclude that the Kuba Kingdom created a civic citizen with respect for rules. The Kuba Kingdom had less conflict and was more prosperous than the neighboring Lele territory. However, these outcomes reflect the direct effects of the Kuba institutions on individual actions, not the population's underlying cultural norms, which are observable only in the absence of the direct effects of Kuba institutions.

After estimating the reduced-form relationship between the Kuba state and rule-following, we then check to see whether these differences arise spuriously due to either selective migration into our sample or to differences in the geography of the traditional Kuba and non-Kuba homelands. It is possible that the differences we find arise due to differential migration from within and outside of the Kuba Kingdom to Kananga. Relying on information of individuals' migration histories, we find no systematic differences in this dimension between Kuba and non-Kuba descendants in our more restrictive samples. In addition, controlling for these observable characteristics does not affect our baseline estimates. We also check whether the differences we find can be explained by differences between the geography of the Kuba and non-Kuba ancestral villages. Using fine- 
grained crop suitability data from the FAO, we show that the geography of the two groups is very similar - especially for the more restrictive samples. In addition, our estimates are robust to controlling for geographic differences.

We then turn to alternative explanations for our findings. The first that we consider is income and prosperity. Due to the presence of a state, the Kuba were, by all accounts, more prosperous than surrounding groups. The persistence of such prosperity may explain part of the difference in rule-following that we observe. Examining a number of measures of prosperity today, we find some evidence - though not robust across all measures and all samples - that Kuba descendants are more prosperous than non-descendants. However, we find that accounting for these differences tends to strengthen the Kuba and non-Kuba differences we estimate. This is intuitive. Kuba descendants are more prosperous, and greater prosperity is often associated with less cheating (e.g., Hruschka et al., 2014).

Another alternative explanation for our finding is that it is due to the Kuba being treated differently during the colonial or post colonial-periods. We check for this using information on colonial investments, namely mission stations, electrical power stations, railway lines, and mines. During the post-colonial period there were virtually no public goods provision nor taxation in our area of study. We thus undertake an alternative strategy by measuring respondents' attitudes towards the former president Joseph Mobutu who was in power from 1965-1997. If Mobutu treated the Kuba and non-Kuba differently during this period, then this would likely be reflected in respondents' attitudes today. We measure these using both survey questions and, due to concerns about truthful self-reporting, we also administered an Implicit Association Test (IAT). ${ }^{11}$

Using these measures of colonial and post-colonial experience, we test for differences between the Kuba and non-Kuba and check the sensitivity of our results to controlling for these differences. Our estimates suggest that these factors are not able to explain the lower rates of rule-following that we observed among the Kuba.

Lastly, we consider the possibility that other cultural traits could have been affected by the Kuba Kingdom and that these could affect behavior in the RAG and the UG with theft. If this were true, then this could invalidate our interpretation of behavior in the games as reflecting cultural norms of rule-following. In particular, we consider whether differences in individuals'

\footnotetext{
${ }^{11}$ The IAT was developed by psychologists to examine individuals' implicit attitudes toward a particular target (see Banaji and Greenwald, 2013). In the IAT we develop, the target is Mobutu.
} 
trust in foreign researchers and/or differences in altruism towards the player 2's in the RAG explain part of the Kuba effect we estimate. Using survey questions to measure trust and using behavior in the dictator game to measure altruism toward player 2, we test for this explanation. We find that neither trust nor altruism is able to account for the lower incidence of rule-following among the Kuba.

Our findings shed light on the relationship between culture and institutions, and they are consistent with a large existing body of evidence showing that socially desirable laws and regulations (as well as monetary incentives) can crowd out beneficial norms. Like our research, these studies find that the presence of laws and institutions - relative to their absence - can undermine intrinsic motivation. In other words, institutions can crowd out cultural norms. The literature documenting these effects is summarized in Bowles and Polania-Reyes (2012), while Deci, Koestner and Ryan (1999) provide a meta-analysis of a large number of experimental studies that generally verify that extrinsic rewards can crowd out intrinsic motivations. ${ }^{12}$

On the other hand, our findings contrast with a number of prior studies that have examined how different aspects of institutions affect various cultural traits. These studies often find evidence for a complementarity between culture and institutions. For example, Becker, Boeckh, Hainz and Woessmann (2015) estimate the impact of differences between the more bureaucratized Habsburg and the Ottoman Empires and find that the former is associated with higher levels of trust and lower levels of corruption today. ${ }^{13}$ Tabellini (2010) examines differences in states' constraints on the executive, finding that within Western Europe, a history of a more constrained executive is associated with higher levels of social capital and trust today. Hruschka et al. (2014) find that people in countries with higher scores in a World Bank index of public good provision cheat less in the resource allocation game. ${ }^{14}$

There are a number of potential explanations for the differences with our results. The main distinction is that the studies are examining different 'treatments' than we do here. Both Becker et al. (2015) and Tabellini (2010) compare different types of states to each other, while our study

\footnotetext{
${ }^{12}$ See also Piff, Stancato, Cote, Mendoza-Denton and Keltner (2012) and Falk and Szech (2013).

${ }^{13}$ See also Grosjean (2011).

${ }^{14}$ Other experimental research also finds complementarities between institutions and culture. For example, Cassar, d'Adda and Grosjean (2014) have participants play a sequence of games, randomly varying the institutional structure of a market game prior to identical one-shot trust games. They find that stronger formal enforcement of cooperative behavior in the market game results in more trust and trustworthiness in the subsequent trust games. Peysakhovich and Rand (2015) use a similar strategy but instead administer repeated prisoner's dilemma games with different institutional structures followed by one-shot games. They find that institutions that generate cooperative behavior in the repeated games generate cooperative spillovers in the one-shot games.
} 
compares the presence of a state to the absence of a state. Hruschka et al. (2014) use variation in public good provision on the national level as the explanatory variable. They also recognize the possibility of co-evolution between their variables of interest and so are therefore interested in estimating the correlation between the two measures without necessarily imposing a causal interpretation. The methodology of our study, on the other hand, is aimed at identifying the causal effect of state formation on rule-following. Due to reverse causality and the presence of omitted factors, this causal effect could be very different than the correlation one observes in the cross-section.

In the spirit of Weber, Johnson (2014) empirically documents a relationship between state institutions and civic mindedness in 17th and 18th century France. The notion that political institutions, particularly state formation, inculcate particular types of values is widespread in the literature on nationalism (e.g., Anderson, 2006, Gellner, 2009). Other scholars have made the opposite argument. In particular many authors have proposed that states induce perverse cultural dynamics which ultimately lead to their collapse, ancient Rome being perhaps the most prominent example (Gibbon, 1996, MacMullen, 1990).

The remainder of the paper is organized as follows. Section 2 describes the historical episode we exploit in our analysis. Section 3 describes the fieldwork undertaken, including the sampling framework and data collection. Section 4 describes the details of our two experimental measures of rule-following and our main findings regarding differences between Kuba and non-Kuba descendants, while section 5 undertakes a more formal analysis estimating the reduced-form effect of the Kuba state. Section 6 tests for omitted factors that may be biasing our estimates, namely selective migration to Kananga and geographic differences between the homelands of the two groups. Section 7 turns to an examination of other potential explanations for our findings, including differences in the colonial and post-colonial experience, current income differences, and current differences in trust and altruism. Section 8 concludes.

\section{Historical Background}

\section{A. Migrations Prior to the Formation of the Kingdom}

Prior to the formation of the Kuba Kingdom there was a series of large migrations to the region, including the migration of the Mongo people who came from the northwest and crossed the 
Sankuru river sometime in the Medieval period. Historian Jan Vansina describes this migration as "part of the general expansion of the southern Mongo... The historian visualizes an expansion over a [broad] front, all along the Sankuru and parts of the lower Kasai. The Leele [Lele] crossed first, then the Bieeng and the Pyaang, then the Ngeende, and then the Bushong." (Vansina, 1978, p. 56)

The migration included many different groups, some of whom were to be integrated into the Kuba Kingdom (the Bushong, Ngeende, Pyang, Bulaang, and Bieeng), and others of whom were not (the Lele). ${ }^{15}$ Vansina $(1978$, p. 5) refers to the group of five clans that later became a part of the Kuba Kingdom as "central Kuba," distinguishing them from other groups that became part of the Kingdom but were not part of the same migration. He refers to this latter group as the "peripheral Kuba" (Vansina, 1963).

The oral history of the central Kuba traces the origin of the world to Mboom who had a son called Woot, the first man. Woot committed incest with his sister Mweel and they were cast out of the primeval village leading to their migration. From this relationship, a series of children were born who are the progenitors of the central Kuba and the Lele (Vansina, 1978, p. 32). In the case of the Lele, Torday (1925, pp. 127-128) records how Woot had a son Nyimi Lele from his incestuous union, but when it became public "there was such an outcry of indignation amongst the people that Woto [Woot] had to order his son to leave the country. With his adherents, Nyimi Lele travelled till he reached the River Katembo (the Loange) which he followed, and there he founded the nation of the Bashilele (sons of Lele) and his descendants were their chiefs."16

The oral history, which attributes a common ancestry to the central Kuba and Lele, is consistent with linguistic evidence. The central Kuba, along with the surrounding groups, speak Bantu languages descended from Mongo and, according to Gunthrie's (1971) classification, both Bushong and Lele diverged from it, indicating common linguistic and cultural roots, while the languages of the Ngeende and Bieeng, for example, are dialects of Bushong.

\section{B. The Formation of the Kuba Kingdom}

The Kuba Kingdom formed in the early 17th century (probably in the 1620s) when an outsider named Shyaam first made himself the chief of the Bushong by overthrowing and killing the exist-

\footnotetext{
${ }^{15}$ The migration routes can be found in Vansina (1990, Map 4.4, p. 124).

${ }^{16}$ See also Wharton (1927, p. 66).
} 
ing chief. He then united the independent villages and small chieftaincies into one large kingdom. His success in forming the Kingdom was likely due to several idiosyncratic characteristics. He was a magician and medicine man, he had travelled widely, and had access to long-distance trade networks. In particular, he participated in the Mbuun trade, which itself was connected with the external Atlantic trade via the Kongo Kingdom. It is believed that he introduced a number of new technologies, including many new world crops (e.g., tobacco, cassava, and maize), and ideas (e.g., knowledge of how to make raffia cloth and palm wine). He is also credited with a number of institutional innovations, such as initiation rituals, ceremonial knives, the royal charm, and the belt of office (Vansina, 1978, pp. 59-65).

The fact that Shyaam was an outsider may seem surprising. However, as discussed by Sahlins (2008), the presence of "stranger kings" is not uncommon historically. He argues that outsiders were often effective at arbitrating existing conflicts because they were not associated with any side or vested interest. ${ }^{17}$ The origins of the Kuba state, particularly its idiosyncratic origins, is consistent with the general view by archaeologists regarding the formation of states in Africa (e.g., MacIntosh, 1988, Monroe, 2013, Monroe and Ogundiran, 2012, Dueppen, 2014).

Shyaam united a collection of independent Bushong chieftaincies east of the Kasai river (rather than a collection of Lele chieftaincies west of the Kasai river) for idiosyncratic reasons. After the establishment of the Kingdom, it expanded to the boundaries shown in figure 1 . The Kingdom was naturally separated from several neighboring societies by three rivers: the Kasai (on the West), the Sankuru (on the North), and the Lulua (on the South). The peoples on the other sides of the rivers, even other "Children of Woot" (namely the Lele) who had migrated to the region with the Bushong, were never unified under a centralized state.

Conventional explanations of state formation in Africa does not explain why the Kuba developed a state but the surrounding peoples did not. Fenske (2014), for example, examines how geographical variability can induce trade, which stimulates state formation. Yet there are no significant geographical differences between the areas inside and outside the Kuba Kingdom. (We examine this more formally in section 6.) According to other theories, such as that of Herbst (2000), population density stimulated state formation in Africa. However, there is no evidence of large differences in population density when the Kuba Kingdom was established. After the

${ }^{17}$ This is an argument similar to the one about the origins of the Podesta system of government in medieval Genoa (Greif, 1998). 
unification of the Kingdom, the population within the Kingdom did indeed expand more rapidly than the surrounding areas. But this was a consequence of state formation and the resulting improvements in agricultural productivity (Vansina, 1978, pp. 177-186). ${ }^{18}$

The Kuba Kingdom was not the only large state in Central Africa, but it was the only state among the peoples living in the region of interest (Vansina, 1966b). None of the surrounding groups, including those who migrated with the Bushong but stayed outside of the Kuba Kingdom, achieved anything close to the same degree of political centralization. Nor did any other groups who occupied the region. For example, the Luluwa, the dominant ethnic group in Kananga and in our sample, are a western offshoot of the Luba. The ethnic group "Lulua" appears to have been created during the colonial period (Vansina, 1966b, pp. 14-15). At the time of colonization, the Luluwa were organized into separate villages under nascent chiefs. Martens (1980, p. 40) notes "The Lulua were organized into small chiefdoms or independent clan groupings with the leader usually being a senior member of the clan." This organization was typical for the groups surrounding the Kuba. This was true of the Chokwe to the southwest (McCulloch, 1951), of the Luntu and the Songe (Vansina, 1966a, pp. 168-169) and the Sala Mpasu to the south (Pruitt, 1973). Other ethnic groups were even less centralized. Douglas (1963), for example, focuses on the lack of centralization and authority among the Lele, noting that they lacked chiefs with any authority, let alone professional bureaucrats, judges, or policemen. ${ }^{19}$ In short, none of the groups surrounding the Kuba Kingdom had the same types of state institutions as the Kuba.

The closest states were the Luba Kingdom, hundreds of miles to the southeast in modern-day Katanga, which formed slightly earlier, the Lunda Kingdom, also hundreds of miles to the south in northern Angola, which formed around the same time as the Kuba Kingdom, and the Kanyok Kingdom, which formed in the 18th century to the southeast of the Kuba Kingdom (Reefe, 1981, Bustin, 1975, Yoder, 1992). Oral histories of these states suggest that they developed independently. ${ }^{20}$ Our sample does not contain individuals whose ancestors lived in these three kingdoms. It does contain individuals who report their ethnicity as 'Luba'. These

\footnotetext{
${ }^{18}$ Moreover, available empirical evidence fails to find a correlation between historical population density and state formation in Africa (Osafo-Kwaako and Robinson, 2013).

${ }^{19}$ The residual Mongo north of the Sankuru were kinship based societies without any level of political centralization and the Cwa even lacked elaborate systems of kinship (Vansina, 1966a, pp. 87-89). Vansina (1978, p. 5) notes that the "Kete and Coofa had only village government. They did not form chiefdoms." Torday and Joyce (1922) describes in detail the political organization of the Songe and Tetela, who were not unified politically, but rather divided into many chiefdoms in which chiefs had intermittent rights to tribute and land and dispensed justice.

${ }^{20}$ The formation of the Luba state seems to be a consequence of a model of governance spreading to Katanga from the east (Reefe, 1981).
} 
Tshiluba-speaking individuals descend from migrants from Luba territories who formed separate communities (outside of the Kuba Kingdom) that were not incorporated into a centralized state. An example are the stateless Coofa, who descend from such Luba migrants. Today, in Kananga, descendants of the stateless migrant Luba are known as 'Luba', while descendants of the Luba Kingdom are known as 'Lubakat', a combination of the words 'Luba' and 'Katanga'. Our sample includes descendants of the stateless 'Luba' and not the 'Lubakat'.

\section{The Organization of the Kuba Kingdom}

The territory of the Kuba Kingdom was divided into nine provinces that were themselves subdivided into counties, each of which had a head chief (Vansina, 1978, p. 128). The Kingdom had executive councils, professional bureaucracies, a military, and police forces. The executive, apart from the king, comprised a system of title holders, called kolm. There were 120 distinct titles in the late 19th century. Though some of these titles were reserved for members of 18 aristocratic clans, the majority were appointed meritocratically, with status being achievement-based. The king interacted with four main councils. The most significant of these was the ishyaaml, which did not include the king. The ishyaaml had fixed rules for establishing a quorum and a fixed membership that included: the kikaam, the highest official in the bureaucracy; the kum ashin, the provincial governors; and the mbyeemy, the ritualist of the court. The ishyaaml met frequently and could veto the king's orders and edicts. If a veto occurred, the issue went to another council, the mbok ilaam, which met in a particular square deep within the palace and included all kolm as members. This council dealt with current affairs and had procedures for reaching a compromise when conflicts arose between the king and the ishyaaml. The other two main councils were the ibaanc and the iyoot, both of which met in special circumstances. The iyoot, for instance, was connected to warfare, and it was where the king informed the kolm about military events and decisions (Vansina, 1978, pp. 145-152).

Thus, an important characteristic of the Kuba state is its division and balance of power. Vansina (1978, p. 147) writes that "The power of the kolm was balanced by that of the king. A refined balance of power between the different groups competing for decision making was

also established through overlapping memberships in other councils and in the representation in ishyaaml of all the groups except the potential successors [to the king]." 
The Kingdom conducted annual censuses which reported births and deaths to the central administration, and it levied annual taxes on all villages in its domain. It also required corvée labor, for example, to build and maintain a kingdom-wide system of roads and bridges, and to build, maintain, and provision the capital. It also regulated economic activity and markets. Overall, the Kuba Kingdom was among the most bureaucratized pre-colonial states in all of sub-Saharan Africa. At time of colonization the central administration in the capital of Mushenge had more than 100 full-time officials (Vansina, 2010, p. 46, Torday and Joyce, 1910, pp. 53-56).

Law enforcement was formally institutionalized in the Kuba Kingdom. In 1892, the police force in the Bushong territory consisted of 40 men, who were led by the son of the king (Sheppard, 1917, pp. 99-100, 139-140); each village in the Kingdom had two policemen (Vansina, 1971, p. 138). Also distinctive, and relevant to our study, is the Kuba Kingdom's elaborate judicial system, which included trial by jury and appellate courts. In this system, there were two judicial fora, the moots and the courts, as well as different levels: the clan, the village, the chiefdom, and the Kingdom. Minor disputes were dealt with by moots, informal assemblies of relatives and kinsmen who heard evidence and arbitrated in public meetings. More serious offenses went to courts, in which a panel of judges with particular expertise or experience in the crime or dispute under consideration, would be selected. From the basic court, appeals could be made to another court headed by a particular kolm, called a baang. From this court, appeal could be made to yet a higher court presided over by the kikaam, the highest bureaucrat in the Kingdom. A final appeal could then be made to what Vansina (1971, p. 138) describes as the "supreme court," where the senior members of the 18 aristocratic clans took part and the king acted as a spectator, ready to grant a stay of execution if necessary. All cases of murder in the Kingdom went directly to the supreme court.

Court cases had well defined procedures. If a person brought a case to a judge $(\mathrm{kolm})$, he or she had to deposit 700 cowrie shells. The case was then directed to the judge most competent in the relevant dispute, who then formed a panel of judges and chose a day for the trial. The defendants were informed of this date, and when the time came, they and the witnesses, called by the defendants or the judges, appeared and gave testimony. The judges then adjourned and made a decision, which could include fines if a guilty verdict was reached. A defendant, if found guilty, could then follow a well-defined procedure to appeal to a higher court, which began by paying a 150 cowrie shell fee to the court that had just handed down the verdict. 
Though the Kuba did not have writing, Vansina describes their "corpus of substantive law" based in part on the principle, "the graver the offense, the heavier the penalty" (Vansina, 1971, p. 141-142). "Kuba courts do not seem to have invoked specific precedents, but legal analogy was used. The scale of penalties alone indicates that comparison between cases was made" (Vansina, 1971, p. 146). Vansina also notes that the legal terminology used clearly indicates that the courts served to provide "justice". For instance, a "case" is referred to as matyeen: "things looked at with care" and "things scrutinized" (Vansina, 1971, p. 144). Statutes and orders by the king also became law.

The sophisticated legal system of the Kuba state made it unique in Central Africa, even when compared to the other large states in this part of the continent. For instance, the Kuba's legal system can be contrasted to Yoder's (1992, p. 96) description of the legal system of the Kanyok state: "even serious crimes, when committed against one's own family, were left to the discretion of the lineage which punished the offender as it saw fit."

\section{The Kuba-Lele and Bushong-Lele Comparison}

Our study is not the first to recognize that the Kuba Kingdom provides a near natural experiment suitable for assessing the long-term impacts of state formation. Historian Jan Vansina and anthropologist Mary Douglas have written extensively comparing the Kuba Kingdom with the stateless Lele. Douglas (1963) compares the Bushong and Lele, writing that "they are historically related, and share many cultural values. On the surface, Lele material culture looks so like a counterpart of Bushong that it is worth comparing the two tribes... Everything that the Lele have or do, the Bushong have more and can do better. They produce more, live better, as well as populating the region more densely than the Lele." (pp. 41-42) Turning to the differences in political institutions, she writes: “The Bushong managed to develop a well-organized political system embracing 70,000 people... By contrast, the largest political unit of the Lele, the village, was smaller than the smallest political unit in the Bushong system." (pp. 50-51)

Just like any society the Lele had disputes and conflicts, but they dealt with them in a different, less institutionalized way than did the Kuba. A central point in Douglas (1963) is that there was no overarching system of authority in Lele territory. She notes that "anyone who has lived with the Lele will agree at once that there was no authority. There was no person or body in a village who could give orders and expect to be obeyed by anyone else." (Douglas, 1963, p. 84). 
In the absence of courts or other legal institutions, murder cases between villages created "blood debts" that were resolved through negotiation of compensation (such as the exchange of a female pawn) between clans (Douglas, 1963, Chapter 8). However, there were no institutions to enforce such compensation, and instead disputes were brokered in a political process known as ku utera. "But in itself [utera] was a neutral piece of political machinery. It could as well be used by the strong against the weak" (pp. 171-172). Indeed, Douglas points out that in such cases, and in stark contrast to the Kuba legal system, "A village did not consider the rights and wrongs of the case offered to them." (p. 172)

\section{E. The Kuba Kingdom during the Colonial and Post-Colonial Periods}

The first European contact with the Kingdom occurred in 1885 when Ludwig Wolf, a doctor who was second in command on the mission of explorer Hermann Wissman, visited the Kingdom. ${ }^{21}$ Wolf never made it much beyond the fringe of the Kingdom, however, and it was an Afro-American Presbytarian minister named William Sheppard who first reached the capital city of Mushenge in 1893. After Sheppard, there is a long series of visitor accounts (e.g. Verner, 1903), culminating in the first fully fledged ethnography/history by Torday and Joyce (1910), who visited the region in $1907 .^{22}$

During the period of the Congo Free State (1885-1908), all parts of Kasai were part of a concession granted to the Compagnie de Kasai, which engaged in intense and brutal rubber collection. ${ }^{23}$ Importantly for our analysis, the impact of the Compagnie de Kasai seems to have been fairly uniform across Kasai in general, and across our area of study in particular (Martens, 1980). Moreover, in 1910 after the Congo had become a Belgian colony, a colonial decree set up a system of indirect rule, whereby African chiefs and traditional political institutions functioned as the lowest level of government of the colony. In the Kuba Kingdom, this form of indirect rule "had a great deal in common with colonial rule elsewhere in Congo" (Vansina, 2010, p. 208). The Kuba were subject to the usual colonial impositions, such as forced crop production, head taxes, and labor services.

Overall, the historical evidence suggests that the Kuba suffered in similar ways to other surrounding peoples during the periods of the Congo Free State and the Belgian Congo. Existing

\footnotetext{
${ }^{21}$ See Bateman (1889), von Wissmann (1891), Martens (1980) and Vansina (2010) for overviews.

${ }^{22}$ Also see the account of Hilton-Simpson (1911), who accompanied them on their expedition.

${ }^{23}$ See the report of British consul Wilfred Thesiger (1909) for an eye witness account of the impact on the Kuba.
} 
first-hand accounts of the Kuba (particularly the Bushong) and the Lele, before and after the colonial period, suggest a great deal of continuity in their institutions and culture. Part of this is no doubt because the Belgian colonial state ruled a vast territory with very few colonial officials and because the region of our study was far from the main hubs of Belgian colonial rule. Historians tend to agree that Kasai was relatively less affected by colonial rule than other parts of Congo.

Unlike other large kingdoms on the African continent, the Kuba Kingdom remained intact during and after colonial rule. In fact, Vansina (2010) titles chapter 7 of his book "A Kingdom Preserved", noting that the Kuba Kingdom was "the only precolonial kingdom to survive nearly intact, the only territory of its kind and its size encapsulated in the colony's administrative grid like a fly in amber" (Vansina, 2010, p. 179). Thus, many of the Kingdom's pre-colonial institutions persisted until independence. This continuity informs the interpretation of our findings. It is unlikely that the low rates of rule-following we observe among Kuba descendants are a function of the collapse of the state or the reduced accountability of traditional rulers that occurred during the colonial period in other parts of Africa (e.g., Mamdani, 1996)

Less information is available on the post-colonial period. After an ill-fated attempt at secession between 1960 and 1962 (Dedeken, 1978), the Kasai region fell into sustained decline during the kleptocratic regime of Joseph Mobutu between 1965 and 1997. ${ }^{24}$ Mobutu's regime was characterized by a severe neglect of infrastructure and public goods provision. There was also very little collection of data; existing censuses from the period are regarded as highly unreliable. Despite this, the Kuba Kingdom persisted, although not immune to the institutional decay that affected all traditional political structures during this period. The Kingdom's persistence was verified by the authors during a visit to Mushenge, the capital of the Kingdom, in the summer of $2013 .{ }^{25}$

\section{Data Collection}

Our sample comprises individuals living in Kananga, the capital of the local province, Kasai Occidental. Kananga lies to the south of the Kuba Kingdom and is about a 300 kilometer drive from the center of the Kuba Kingdom and its capital Mushenge. Thus, none of the individuals

\footnotetext{
${ }^{24}$ See Callaghy (1984), Turner and Young (1985), and Van Reybrouck (2015) for a description of this experience.

${ }^{25}$ During the trip, we met with the royal court to confirm information from the secondary literature and to learn more about the Kingdom's surviving customs and institutions.
} 
in our sample were living in or surrounding the Kuba Kingdom at the time of the survey. As noted in the introduction, a Kananga-based sample allows us to better identify cultural channels. By examining individuals removed from their original institutional environments, but now living in the same city, we can be more confident that our findings are driven by differences arising from internal norms, rather than differences in the external setting. ${ }^{26}$ It was also more feasible to collect data in the city given the poor transportation infrastructure of the region.

The data were collected in June, July, and August of 2013 and 2014, the dry season in Kananga. Because a census for the city does not exist, we used Google satellite imagery to randomly sample households. We first divided Kananga into nine cells, which are shown in figure 2. We then selected a random sample, using a two-stage cluster sampling method. We selected a fixed number of polygons in each grid cell, with a probability of selection proportional to population. We then randomly selected a fixed number of houses within each polygon. The polygons are also shown in figure 2. In total, our random sample consists of 2,097 households (1,031 in 2013 and 1,066 in 2014).

The random sample yielded a relatively small number of 'treated' observations with ancestors who were from the Kuba Kingdom. To increase the number of households from the ethnic groups of interest, we used an additional sampling strategy. Neighborhoods/polygons that were likely to have Kuba and Lele inhabitants were identified in consultation with local Kuba and Lele leaders. These neighborhoods were deliberately selected, but the sampling procedure within the resulting polygons remained random. That is, within the polygons, households were randomly selected. The targeted sample includes 788 individuals from 33 targeted polygons from 2013, and 1,908 individuals across 66 targeted polygons from 2014. Therefore, the total sample from 2013 includes 1,819 individuals and 3,345 individuals from 2014. The finer details of the sampling procedure are provided in the paper's online appendix.

From our sample, we then selected the subset of individuals relevant for our study. These included all individuals who: (i) have an origin village or birth village in Mweka, a district whose borders are nearly identical to that of the historical Kuba Kingdom; (ii) have an origin or birth village in the districts contiguous to Mweka; or (iii) have an origin village or birth village in other districts, but who belong to an ethnic group represented in Mweka, namely Kete, Kuba, or Lele.

\footnotetext{
${ }^{26}$ This is analogous to prior studies that examine migrants to the United States or Europe, to try and understand cultural differences arising from the home countries. See for example Giuliano (2007), Fernandez and Fogli (2009) or Alesina et al. (2013).
} 


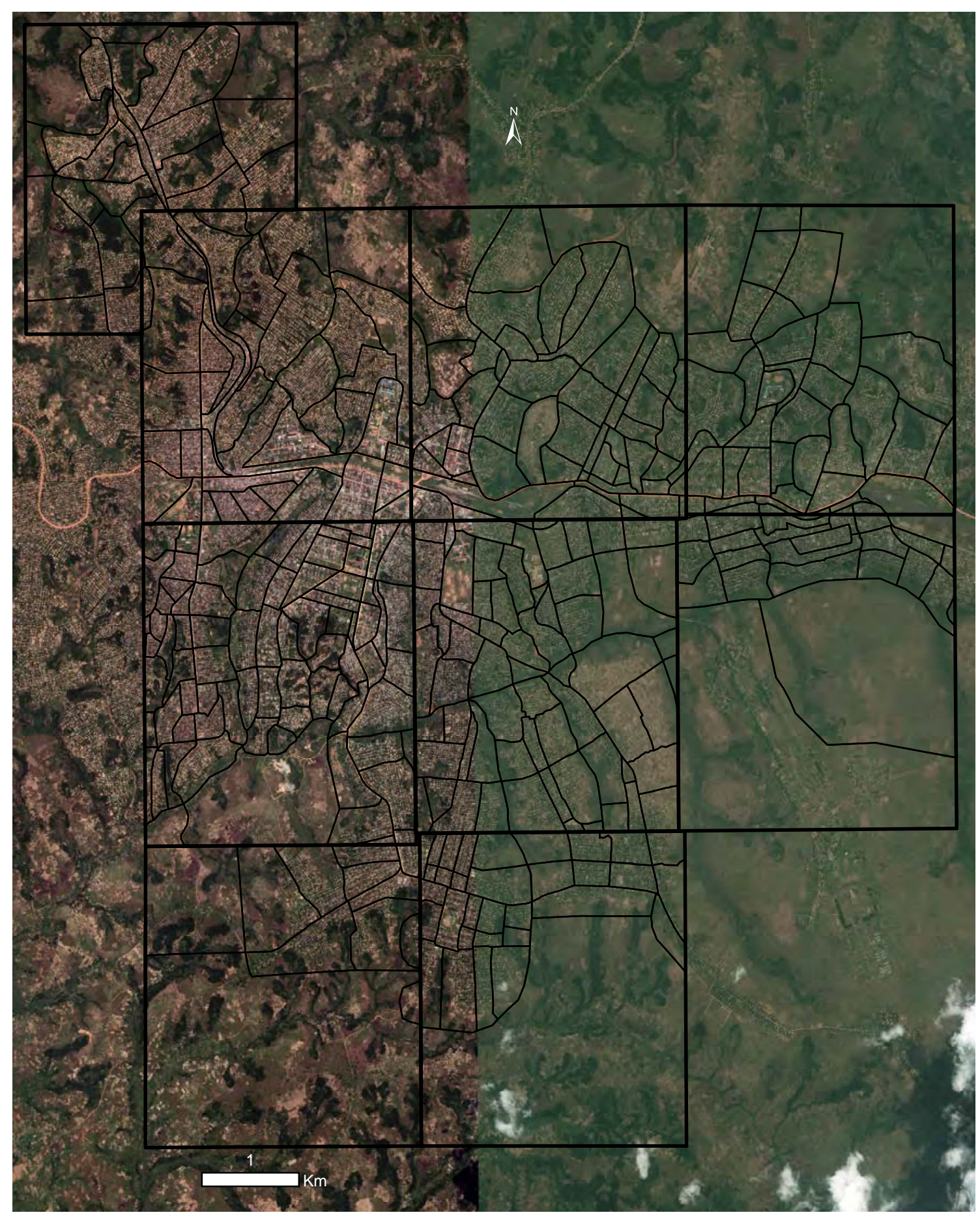

Figure 2: Satellite imagery of Kananga, showing grid cells and polygons. 


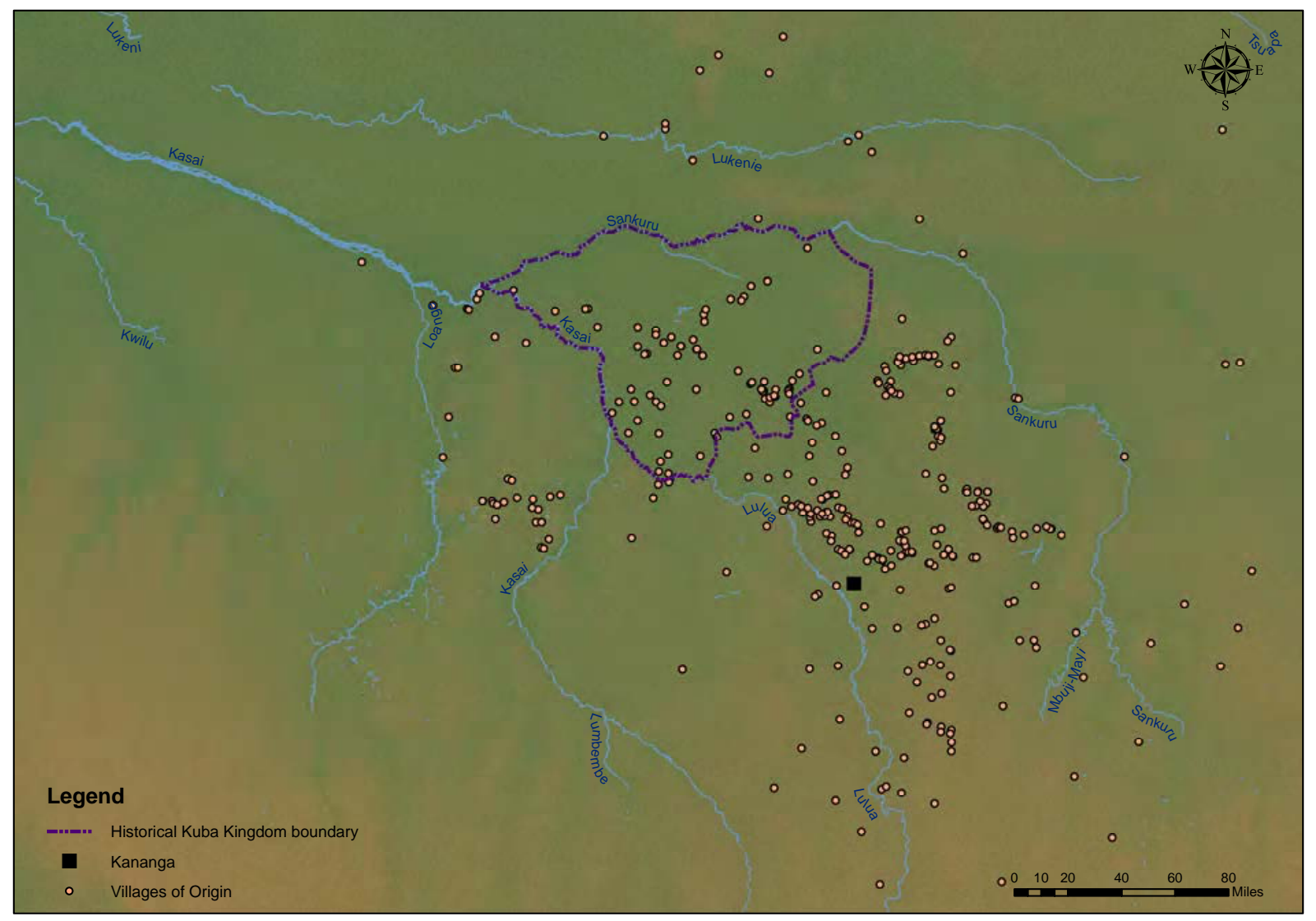

Figure 3: Map showing Kananga and the location of the origin villages within the sample.

In total, 499 individuals satisfied this criterion.

Participants in our study were visited by enumerators three times after the initial screening survey. In the first visit, we collected information on individuals' migration history, basic demographic information, measures of income, trust, and political attitudes. During the second visit, we administered the dictator game (DG) and the ultimatum game (UG) with the potential for theft. During the third visit, we administered the resource allocation game (RAG). The results we present here include all of the behavioral games that were administered as part of this project. We are not selectively reporting results from a larger set of games. The RAG and the UG with theft are used as measures of rule-following. ${ }^{27}$ We describe the details of these games below.

\footnotetext{
27 As we explain in section 7, we use the behavior in the DG as a measure of altruism when examining this as a potential alternative mechanism that explains our baseline finding.
} 
Table 1: Ethnic groups in the sample.

\begin{tabular}{lcc}
\hline \hline Reported Ethnicity & $\begin{array}{c}\text { Number of } \\
\text { Participations }\end{array}$ & $\begin{array}{c}\text { Percentage of } \\
\text { Participants }\end{array}$ \\
\hline Luluwa & 160 & 27.97 \\
Kuba & 80 & 13.99 \\
Kete & 63 & 11.01 \\
Luntu & 58 & 10.14 \\
Lele & 44 & 7.69 \\
Bindi & 40 & 6.99 \\
Luba & 22 & 3.85 \\
Dekese & 10 & 1.75 \\
Songe & 9 & 1.57 \\
Tetela & 7 & 1.22 \\
Tshokwe & 2 & 0.35 \\
Others (1 of each) & 4 & 0.70 \\
Total & 499 & 100 \\
\hline
\end{tabular}

\section{Characteristics of the sample}

The ethnic composition of the sample is reported in table 1 . In total, there are 80 individuals (14\%) who report being Kuba. Ancestral villages and their relation to the historical boundary of the Kuba Kingdom are shown in figure 3. The figure also shows Kananga, the study location. The 449 individuals in our analysis are from 15 different ethnic groups. The dominant ethnic group in the region and in Kananga is the Luluwa. The other large ethnic groups in the sample are the Kete, Luntu, Lele, and Bindi.

Among the 8o Kuba descendants, 62 (77\%) are descendants of the "central Kuba", namely those who descended from Woot. Further, 38 of the $80(48 \%)$ are Bushong. This distribution is very similar to the distribution reported in Vansina (1978, p. 5). In 1953, he calculated that $63 \%$ of the villages within the Kingdom were occupied by the "central Kuba".

\section{Description of Experimental Measures of Rule-Following and Cheating}

\section{Resource Allocation Game (RAG)}

Our primary experimental measure of interest is the recently developed resource allocation game (RAG), a non-strategic game that measures the extent to which participants follow the rules 
(Hruschka et al., 2014). ${ }^{28}$ For a single round of the game, the individual is given a six-sided die with three sides black and three sides white. The individual is also given a stack of thirty IOOCF bills (3,OOOCF in total). This is a significant amount, approximately $\$$ US 3.25 , which is equal to about 2-3 days wages. The participant is told that the stack of bills is to be divided between herself and another party. The other party is either a citizen from Kananga, a coethnic from Kananga, a non-coethnic from Kananga, or the local provincial government (to be used in a public works project). The participant is told to allocate the money according to the following procedure. First, the participant associates black with one of the two parties (e.g., herself or the government) and white with the other party. Then she rolls the die and observes the color that is rolled. If it is white and she had mentally associated white with herself, then she puts the 10ocF bill in an envelope marked for her. If she had mentally associated white with the other party, then she puts the 100cF bill in the envelope for the other party.

Participants repeat this procedure 30 times, each time making a new color association decision. The task is performed by the participant alone in the privacy of a tent, and is not observed by anyone including the person administering the game. Participants are to seal both envelopes in private, keep the envelope that is for themselves, and place the envelope for the other party in a bag outside of the tent. Participants play the game four times, dividing the money between themselves and one of the four parties mentioned above. ${ }^{29}$ After all games were played, the enumerator brought the bag back to the central office. Thus, the enumerator never physically handled the envelopes directly. Prior to the game being played, it was made clear to the participants that the envelopes would not be opened by the enumerator and would be brought back to a central office, where they would be opened by one person, who would never tell anyone the contents of the envelope.

The baseline difference between Kuba and non-Kuba descendants is shown in figure 4a, which reports the average amount allocated to the other party. The figure reports this for each of the four different versions of the RAG, as well as the average across the four versions. If individuals were following the rules, then on average the other party should receive half of the 3,OoocF endowment, or $1,500 \mathrm{CF}$. Yet for both Kuba and non-Kuba participants, the average amount allocated to the

\footnotetext{
${ }^{28}$ For a similar experiment that also tests for rule breaking see Fischbacher and Follmi-Heusi (2013).

${ }^{29} \mathrm{After}$ the games were completed, we distributed the money to the other parties as stated to the participants. Further details of the RAG, as well as other experimental games administered, are reported in the online appendix.
} 
other party (across the four games) is 1,002 (or 33\%), which is well below $1,500 \mathrm{CF}(50 \%)$. $^{30}$ In addition, we find that Kuba descendants consistently allocate less to the other party than nonKuba descendants.

In figure $4 \mathrm{~b}$, we report the same summary measure of cheating separately for the six largest ethnic groups in the sample (see table 1 ). We see that not only do the Kuba contribute less than the average of the other ethnic groups, but they contribute less than all of the other primary ethnic groups in the sample (including the Lele). ${ }^{31}$

\section{The Ultimatum Game with Theft}

The RAG imposes a set of unfamiliar rules and instructions on our participants. The benefit of this is that because the rules are foreign to all, they are likely viewed equally by everyone in our sample, facilitating a credible comparison of the control and treatment groups. ${ }^{32}$ Using a more familiar set of rules generates the possibility that the rules have differential legitimacy across different groups. However, we recognize there is a trade off and one may be concerned that the rules of the RAG are arbitrary and unrealistic to participants. Given this concern, we supplement our RAG measure with an alternative measure of rule-breaking, where the rule being broken is less ad hoc and strange to participants.

The second measure of rule-breaking is based on participants' actions in a variant of the standard ultimatum game (UG). In the game, player 1 proposes a division of 1 , ooocF between herself and the other player. Player 2 then chooses whether to accept or reject the division. If player 2 accepts, then the players receive the corresponding amounts offered by player 1 in the suggested division. If player 2 rejects, then both players receive zero.

Each participant played the one-shot anonymous game six times, three times as player 1 and three times as player two. In the three games as either player 1 or player 2, the player was paired

\footnotetext{
$3^{30}$ Hruschka et al. (2014) implemented the RAG across eight samples from six countries. In their game player 2 was a randomly chosen person that belonged to a an outgroup, with the definition varying by sample. The behavior varied across the samples, ranging from $37.4 \%$ being allocated to player 2 (in Fiji) to $55.1 \%$ being allocated to player 2 in a religious urban sample from the U.S. McNamara, Norenzayan and Henrich (2014) implemented the RAG in Fiji with religious primes and a secular authority prime. The average allocation to player 2, who was an out-group member was $37 \%$. By comparison, in our full sample and across all games, approximately $33 \%$ was allocated to the other player.

${ }^{31}$ In appendix figure A9, we report the full distribution of offers for Kuba and non-Kuba respondents, and for each of the three samples of interest. The support of the distributions is similar between the two groups, but lower-thanaverage allocations are relatively more frequent among Kuba descendants and greater-than-average allocations are relatively less frequent.

${ }^{32}$ If individuals have different views about foreign researchers, then they may have different views about the legitimacy of the rules. We address this possibility in section 7 .
} 


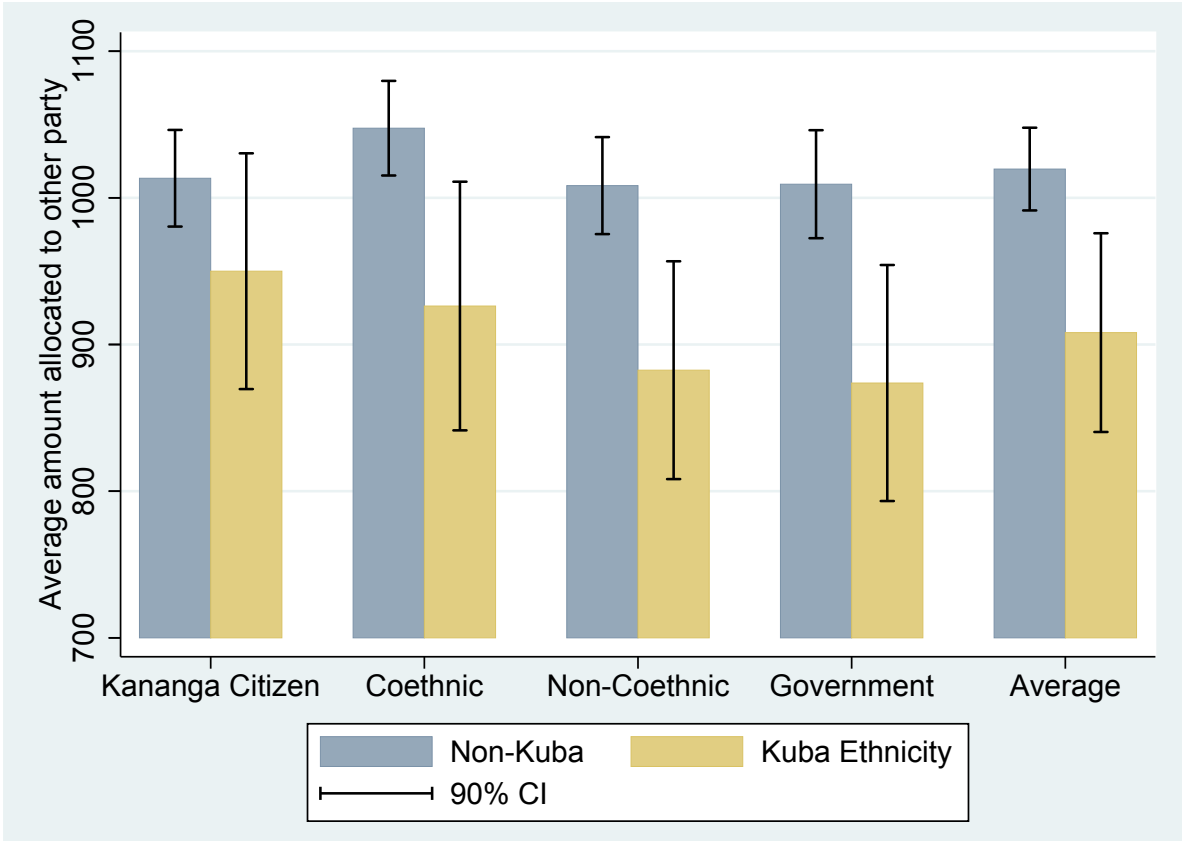

(a) Average allocations made by Kuba and non-Kuba descendants.

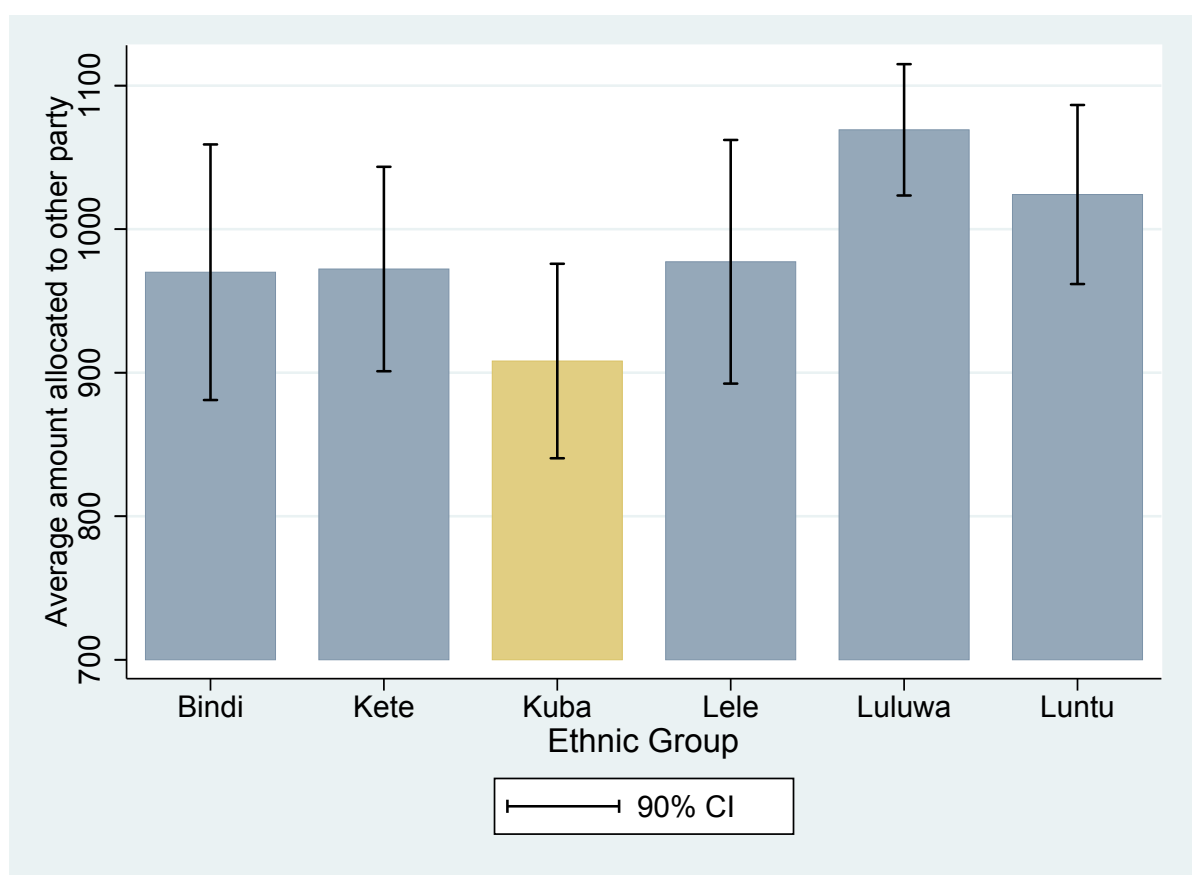

(b) Average allocations made by six largest ethnic groups.

Figure 4: Amount allocated (of 3,oooCF) to the other party in the RAG. 
with an anonymous partner: (i) a citizen of Kananga, (ii) a coethnic from Kananga, and (iii) a non-coethnic from Kananga. For each round, respondents chose their strategy as player 1 (the proposed division of the $1, \mathrm{OOOCF}$ ) and as player 2 (making acceptance and rejection decisions for the possible divisions proposed by player 1 ).

An important difference between our version of the UG and standard implementations of the UG is that we did not use computers or tablets. Instead, participants made their offers as player 1 in private (in a tent) by dividing a stack of ten IOOCF bills into two piles. The portion of the proposed division for player 2 was placed in an envelope marked for player 2, and the portion for player 1 was placed in an envelope for player 1 . Both envelopes were sealed by player 1 and placed in a bag sitting just outside of the tent. Prior to the game being played, it was made clear to the participant that the envelope would not be opened by the enumerator and would be brought back to a central office, where their offer would be randomly matched to acceptance-rejection decisions of another anonymous individual in our sample. Then, the payouts of the two players would be determined and given to two participants during the next visit.

Because individuals made decisions in private and physically handled the money, they had the opportunity to steal by hiding some of the money on their person (e.g., in a pocket). Although doing this would reduce the amount offered to player 2 in the game, it ensured that they received this amount with certainty, independent of the decision of player 2.

In our sample, $4.8 \%$ of participants stole money in at least one round of the UG. Among the Kuba, $10.0 \%$ stole, while among the non-Kuba 3.8\% stole. The distribution of the average amount missing by ethnic group is shown in figure 5.33 Consistent with the results from the RAG, we see that the Kuba are the group most likely to break the rules and steal money during the game.

\section{Baseline Estimates}

We now turn to a more formal test of the long-term effects of the Kuba Kingdom. Specifically, we estimate the following equation:

$$
y_{i}=\alpha+\beta I_{i}^{K u b a}+\mathbf{X}_{i} \boldsymbol{\Gamma}+\varepsilon_{i}
$$

where $i$ indexes individuals. $I_{i}^{K u b a}$ is an indicator variable that equals one if individual $i^{\prime}$ s selfreported ethnicity is Kuba. Notice that we collected data also on sub-ethnicities, so that the

\footnotetext{
${ }^{33}$ The analogous figure for the fraction within each group that stole looks similar and is reported in appendix table Aio.
} 


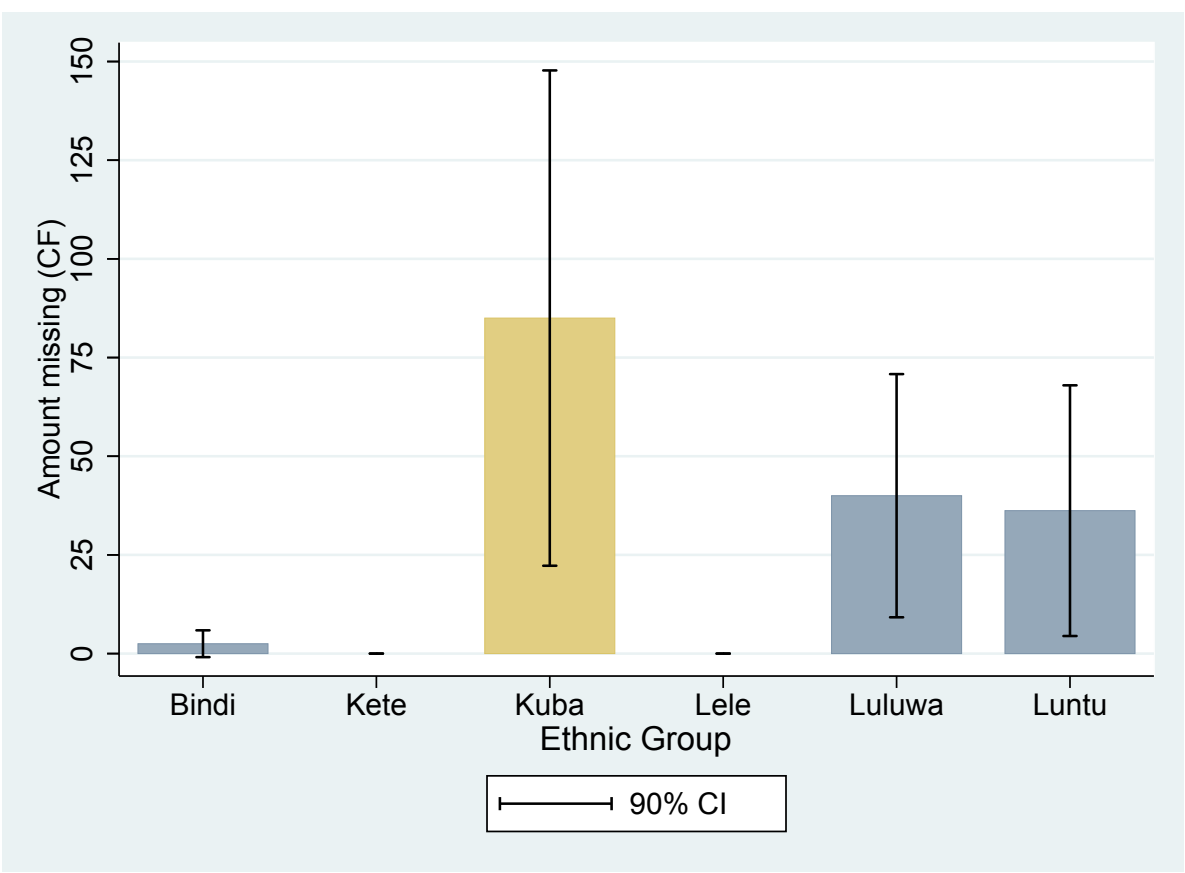

Figure 5: Average amount of money missing from three rounds of the Ultimatum Game, by ethnic group.

Bushong are both Kuba and Bushong. The vector of individual-level covariates, $\mathbf{X}_{i}$, includes age (in years), age squared, a female gender indicator variable, and an indicator that equals one if the individual participated in 2014 (rather than 2013).

Motivated by the historical natural experiment, we estimate equation (1) using three different samples: (i) all observations in the sample, and (ii) descendants of the Central Kuba and the Lele only, (iii) descendants of the Bushong and the Lele only.

Estimates of equation (1) are reported in table 2. Panel A reports estimates of equation (1) without covariates, while panel B reports estimates with the baseline set of control variables. Columns 1-3 report estimates using the average amount allocated to the other party in the four rounds of the RAG as our measure of rule-following; each column reports estimates from one of the samples of interest. We find that with or without covariates and for all three samples, the coefficient for the Kuba ethnicity indicator is negative and statistically significant. ${ }^{34}$ The size of the Kuba effect tends to increase slightly as we move to the more restrictive samples that compare ethnic groups that were culturally homogeneous prior to the formation of the Kingdom.

\footnotetext{
${ }^{34}$ As we report in appendix table A4, one reaches the same conclusion by estimating equation (1) using the outcomes in each of the different rounds separately. The behavior in the different games also provides a check on the sensibility of the RAG measure. For example, we find that cheating (less allocation to the other party) is greater when playing against a non-coethnic than a coethnic, and that the amount of cheating when playing against a citizen of Kananga is between these two (see the means reported appendix table $\mathrm{A}_{4}$ ).
} 
Table 2: Baseline estimates in the RAG and UG with theft.

\begin{tabular}{|c|c|c|c|c|c|c|}
\hline & \multicolumn{3}{|c|}{$\begin{array}{l}\text { Average amount allocated to other party (of } \\
3000 \mathrm{CF} \text { ) in the RAG: }\end{array}$} & \multicolumn{3}{|c|}{ Amount of money missing in UG } \\
\hline & Full sample & $\begin{array}{c}\text { Central Kuba \& } \\
\text { Lele }\end{array}$ & $\begin{array}{c}\text { Bushong \& } \\
\text { Lele }\end{array}$ & Full sample & $\begin{array}{c}\text { Central Kuba \& } \\
\text { Lele }\end{array}$ & $\begin{array}{c}\text { Bushong \& } \\
\text { Lele }\end{array}$ \\
\hline & (1) & $(2)$ & (3) & (4) & (5) & $(6)$ \\
\hline & \multicolumn{6}{|c|}{ Panel A. No covariates } \\
\hline Kuba ethnicity indicator & $\begin{array}{c}-111.51^{* * *} \\
(42.19)\end{array}$ & $\begin{array}{c}-141.21^{* *} \\
(70.84)\end{array}$ & $\begin{array}{c}-139.88^{*} \\
-81.52\end{array}$ & $\begin{array}{l}59.46^{* *} \\
(25.09)\end{array}$ & $\begin{array}{l}103.28 * \\
(57.22)\end{array}$ & $\begin{array}{l}121.05^{*} \\
(65.99)\end{array}$ \\
\hline Observations & 499 & 105 & 82 & 499 & 105 & 82 \\
\hline \multirow[t]{2}{*}{ R-squared } & 0.01 & 0.04 & 0.04 & 0.01 & 0.03 & 0.04 \\
\hline & \multicolumn{6}{|c|}{ Panel B. With baseline covariates } \\
\hline Kuba ethnicity indicator & $\begin{array}{l}-88.47^{* *} \\
(41.39)\end{array}$ & $\begin{array}{c}-165.37^{* *} \\
(70.92)\end{array}$ & $\begin{array}{c}-209.91^{* *} \\
(81.33)\end{array}$ & $\begin{array}{l}58.23^{* *} \\
(25.34)\end{array}$ & $\begin{array}{l}140.24^{* *} \\
(59.27)\end{array}$ & $\begin{array}{l}150.70^{* *} \\
(69.48)\end{array}$ \\
\hline \multicolumn{7}{|l|}{ Covariates: } \\
\hline Age & $\begin{array}{c}1.72 \\
(5.18)\end{array}$ & $\begin{array}{c}-6.50 \\
(13.47)\end{array}$ & $\begin{array}{l}-17.50 \\
(17.08)\end{array}$ & $\begin{array}{l}6.53^{* *} \\
(3.17)\end{array}$ & $\begin{array}{l}19.18^{*} \\
(11.26)\end{array}$ & $\begin{array}{c}16.91 \\
(14.59)\end{array}$ \\
\hline Age squared & $\begin{array}{l}-0.008 \\
(0.055)\end{array}$ & $\begin{array}{c}0.071 \\
(0.150)\end{array}$ & $\begin{array}{c}0.237 \\
(0.190)\end{array}$ & $\begin{array}{l}-0.070^{* *} \\
(0.033)\end{array}$ & $\begin{array}{l}-0.230^{*} \\
(0.125)\end{array}$ & $\begin{array}{l}-0.213 \\
(0.162)\end{array}$ \\
\hline Female & $\begin{array}{c}-2.99 \\
(30.41)\end{array}$ & $\begin{array}{c}-127.53^{*} \\
(73.70)\end{array}$ & $\begin{array}{l}-136.69 \\
(89.56)\end{array}$ & $\begin{array}{c}-2.32 \\
(18.62)\end{array}$ & $\begin{array}{l}-97.55 \\
(61.59)\end{array}$ & $\begin{array}{l}-86.58 \\
(76.52)\end{array}$ \\
\hline Survey year $=2014$ & $\begin{array}{c}182.00^{* * *} \\
(31.03)\end{array}$ & $\begin{array}{c}246.06^{* * *} \\
(72.58)\end{array}$ & $\begin{array}{c}259.30^{* * *} \\
(83.12)\end{array}$ & $\begin{array}{l}-16.84 \\
(19.00)\end{array}$ & $\begin{array}{l}-51.85 \\
(60.66)\end{array}$ & $\begin{array}{l}-39.62 \\
(71.01)\end{array}$ \\
\hline Mean of dep var & $1,001.75$ & 895.24 & 912.50 & 35.07 & 60.00 & 56.10 \\
\hline Observations & 499 & 105 & 82 & 499 & 105 & 82 \\
\hline$R$-squared & 0.08 & 0.16 & 0.17 & 0.02 & 0.09 & 0.08 \\
\hline
\end{tabular}

Although there are a number of potential explanations for this pattern, it is consistent with an upward bias arising from pre-existing cultural differences that affected selection into treatment. That is, the ethnic groups that were naturally more inclined to have a greater respect for authority might have been more likely to have become a part of the Kuba Kingdom.

Columns 4-6 of table 2 report estimates using the total amount missing in the three rounds of the UG as the dependent variable. ${ }^{35}$ Using this second measure, we also find that Kuba descendants are less likely to follow rules. The coefficient on the Kuba indicator variable is positive and significant. As with the RAG measure, we find larger estimates of the Kuba effect when we restrict the sample to ethnic groups that were culturally homogeneous prior to the

\footnotetext{
${ }^{35}$ The results are qualitatively identical if one uses an indicator variable for the incidence of any missing money rather than the amount missing.
} 
formation of the Kingdom.

Taken together, the evidence suggests that the Kuba state is associated with a deterioration of intrinsic motivations to follow the rules. This does not mean that the Kuba Kingdom was not a successful and well-functioning state. From the historical and anthropological literature, we know that it was. Although the state was prosperous and orderly, the evidence suggests that it eroded the intrinsic propensity of its subjects to follow rules even when enforcement is absent.

\section{Examining Potential Confounders: Migration and Geography}

\section{A. Differential Selection of Migrants}

As discussed, by examining individuals who no longer live in the treatment or control regions, we are better able to identify a purely cultural channel. All individuals in our sample either migrated from their origin village themselves, or their ancestors migrated at some point in the past. The vast majority of migration to cities is from rural villages, due to the better economic opportunities available in cities. Among the 195 individuals in our sample who were born outside of Kananga and migrated as adults, $144(74 \%)$ migrated because of greater educational (87 people) or economic (57 people) opportunities in the city. Most of the remaining, an additional 23 (12\%), migrated because of marriage. See appendix table $\mathrm{A}_{3}$ for the full distribution of reasons for migration.

Despite the economic motivation behind migration, there remains the concern that individuals who live in Kananga today underwent a selection process that differed systematically between Kuba and non-Kuba descendants, thereby biasing our estimates. We check for differences in observables between the Kuba and non-Kuba populations in each of our three samples of interest. These are reported in table 3 .

The first set of characteristics we examine are measures of whether individuals in our sample are recent migrants. We asked participants if they were born in Kananga and the year in which they moved to Kananga, which combined with their year of birth, could be used to calculate the fraction of their life that was spent living in Kananga. We also constructed three variables aimed at measuring the extent to which individuals are integrated into the broader community in Kananga rather than into an ethnic enclave. We asked individuals about their five closest friends and used this to calculate the fraction of these friends that are coethnics. Using information 
Table 3: Immigration-related characteristics of treatment and control samples.

\begin{tabular}{|c|c|c|c|c|c|c|c|c|c|}
\hline & Kuba & Non-Kuba & Difference & $\begin{array}{c}\text { Central } \\
\text { Kuba }\end{array}$ & Lele & Difference & Bushong & Lele & Difference \\
\hline Immigrant indicator & $\begin{array}{c}0.575 \\
(0.056) \\
80\end{array}$ & $\begin{array}{c}0.530 \\
(0.024) \\
419\end{array}$ & $\begin{array}{c}0.045 \\
(0.061) \\
499\end{array}$ & $\begin{array}{c}0.525 \\
(0.065) \\
61\end{array}$ & $\begin{array}{c}0.591 \\
(0.075) \\
44\end{array}$ & $\begin{array}{c}-0.066 \\
(0.099) \\
105\end{array}$ & $\begin{array}{c}0.526 \\
(0.082) \\
38\end{array}$ & $\begin{array}{c}0.591 \\
(0.075) \\
44\end{array}$ & $\begin{array}{c}-0.0646 \\
(0.111) \\
82\end{array}$ \\
\hline Fraction of life in Kananga & $\begin{array}{c}0.570 \\
(0.045) \\
80\end{array}$ & $\begin{array}{c}0.683 \\
(0.018) \\
418\end{array}$ & $\begin{array}{c}-0.114^{* *} \\
(0.046) \\
498\end{array}$ & $\begin{array}{c}0.594 \\
(0.053) \\
61\end{array}$ & $\begin{array}{c}0.496 \\
(0.065) \\
44\end{array}$ & $\begin{array}{c}0.098 \\
(0.083) \\
105\end{array}$ & $\begin{array}{c}0.591 \\
(0.068) \\
38\end{array}$ & $\begin{array}{c}0.496 \\
(0.065) \\
44\end{array}$ & $\begin{array}{c}0.095 \\
(0.094) \\
82\end{array}$ \\
\hline $\begin{array}{l}\text { Proportion of } 5 \text { closest } \\
\text { friends that are coethnic }\end{array}$ & $\begin{array}{c}0.362 \\
(0.033) \\
80\end{array}$ & $\begin{array}{c}0.473 \\
(0.017) \\
417\end{array}$ & $\begin{array}{c}-0.110^{* * *} \\
(0.041) \\
497\end{array}$ & $\begin{array}{c}0.370 \\
(0.039) \\
61\end{array}$ & $\begin{array}{c}0.388 \\
(0.047) \\
43\end{array}$ & $\begin{array}{c}-0.0180 \\
(0.062) \\
104\end{array}$ & $\begin{array}{c}0.409 \\
(0.052) \\
38\end{array}$ & $\begin{array}{c}0.388 \\
(0.047) \\
43\end{array}$ & $\begin{array}{c}0.021 \\
(0.070) \\
81\end{array}$ \\
\hline $\begin{array}{l}\text { Share of own-ethnicity in } \\
\text { neighborhood }\end{array}$ & $\begin{array}{c}0.0942 \\
(0.015) \\
80\end{array}$ & $\begin{array}{c}0.343 \\
(0.016) \\
419\end{array}$ & $\begin{array}{c}-0.249^{* * *} \\
(0.036) \\
499\end{array}$ & $\begin{array}{c}0.106 \\
(0.018) \\
61\end{array}$ & $\begin{array}{c}0.134 \\
(0.025) \\
44\end{array}$ & $\begin{array}{c}-0.028 \\
(0.030) \\
105\end{array}$ & $\begin{array}{c}0.131 \\
(0.028) \\
38\end{array}$ & $\begin{array}{c}0.134 \\
(0.025) \\
44\end{array}$ & $\begin{array}{c}-0.003 \\
(0.038) \\
82\end{array}$ \\
\hline $\begin{array}{l}\text { Ethnic diversity of } \\
\text { neighborhood }\end{array}$ & $\begin{array}{c}0.654 \\
(0.017) \\
80\end{array}$ & $\begin{array}{c}0.557 \\
(0.010) \\
419\end{array}$ & $\begin{array}{c}0.097^{* * *} \\
(0.023) \\
499\end{array}$ & $\begin{array}{c}0.670 \\
(0.020) \\
61\end{array}$ & $\begin{array}{c}0.660 \\
(0.025) \\
44\end{array}$ & $\begin{array}{c}0.010 \\
(0.032) \\
105\end{array}$ & $\begin{array}{c}0.669 \\
(0.029) \\
38\end{array}$ & $\begin{array}{c}0.660 \\
(0.025) \\
44\end{array}$ & $\begin{array}{c}0.008 \\
(0.038) \\
82\end{array}$ \\
\hline
\end{tabular}

on the ethnic composition of neighborhoods in Kananga from the screening surveys (with a sample of approximately 5,500), we calculated for each participant the share of individuals in their neighborhood that are of the same ethnicity, as well as the ethnic diversity of their neighborhood, measured as one minus the Herfindahl index of ethnic concentration.

Looking at the five measures, we find statistically significant differences between Kuba and non-Kuba. Kuba descendants have spent less of their life in Kananga on average. We also find that Kuba descendants have fewer close friends who are coethnics, live in neighborhoods with fewer coethnics, and live in more ethnically diverse neighborhoods. Thus, the Kuba sample appears to more strongly reflect characteristics typical of immigrants than the non-Kuba sample. However, in the restricted samples, these differences disappear. We find no statistically significant difference in any of the measures between central Kuba and Lele, or Bushong and Lele. As well, the lack of statistical significance is not due to larger standard errors, but to differences that converge towards zero.

To be as conservative as possible, we re-estimate equation (1) while controlling for the five measures from table 3. The estimates, reported in table 4 , show that overall our estimates are robust to the inclusion of these controls. Thus, we feel that it is unlikely that our baseline findings are due to differential selection of migrants to Kananga. 
Table 4: Controlling for immigration-related characteristics.

\begin{tabular}{|c|c|c|c|c|c|c|}
\hline & \multicolumn{3}{|c|}{$\begin{array}{l}\text { Average amount allocated to other party (of } \\
3000 \mathrm{CF} \text { ) in the RAG: }\end{array}$} & \multicolumn{3}{|c|}{ Amount of money missing in UG } \\
\hline & $\begin{array}{c}\text { Kuba vs. all } \\
\text { others }\end{array}$ & $\begin{array}{l}\text { Central Kuba } \\
\text { vs. Lele }\end{array}$ & $\begin{array}{l}\text { Bushong vs. } \\
\text { Lele }\end{array}$ & $\begin{array}{c}\text { Kuba vs. all } \\
\text { others }\end{array}$ & $\begin{array}{c}\text { Central Kuba } \\
\text { vs. Lele }\end{array}$ & $\begin{array}{l}\text { Bushong vs. } \\
\text { Lele }\end{array}$ \\
\hline & (1) & $(2)$ & $(3)$ & $(4)$ & (5) & (6) \\
\hline Kuba ethnicity indicator & $\begin{array}{l}-43.42 \\
(42.48)\end{array}$ & $\begin{array}{c}-170.00^{* *} \\
(73.26)\end{array}$ & $\begin{array}{c}-231.50^{* * *} \\
(84.99)\end{array}$ & $\begin{array}{c}69.74^{* * *} \\
(26.69)\end{array}$ & $\begin{array}{c}123.02^{* *} \\
(61.22)\end{array}$ & $\begin{array}{l}129.01^{*} \\
(73.28)\end{array}$ \\
\hline Immigrant indicator & $\begin{array}{c}200.15^{* * *} \\
(54.13)\end{array}$ & $\begin{array}{l}339.21 \\
(262.7)\end{array}$ & $\begin{array}{l}437.42 \\
(322.2)\end{array}$ & $\begin{array}{c}-2.96 \\
(34.01)\end{array}$ & $\begin{array}{c}191.14 \\
(219.51)\end{array}$ & $\begin{array}{c}22.57 \\
(277.85)\end{array}$ \\
\hline Frac of life in Kananga & $\begin{array}{c}159.34^{* *} \\
(73.59)\end{array}$ & $\begin{array}{c}278.51 \\
(316.85)\end{array}$ & $\begin{array}{c}431.41 \\
(386.26)\end{array}$ & $\begin{array}{c}14.65 \\
(46.23)\end{array}$ & $\begin{array}{c}304.01 \\
(264.76)\end{array}$ & $\begin{array}{c}162.18 \\
(333.06)\end{array}$ \\
\hline Proportion of 5 closest friends that are coethnics & $\begin{array}{l}-30.09 \\
(54.39)\end{array}$ & $\begin{array}{c}73.25 \\
(116.09)\end{array}$ & $\begin{array}{c}185.1 \\
(136.01)\end{array}$ & $\begin{array}{c}17.50 \\
(34.17)\end{array}$ & $\begin{array}{l}178.00^{*} \\
(97.00)\end{array}$ & $\begin{array}{c}135.2 \\
(117.28)\end{array}$ \\
\hline Share of own-ethnicity in neighborhood & $\begin{array}{c}-207.2^{* *} \\
(95.54)\end{array}$ & $\begin{array}{c}-211.13 \\
(234.27)\end{array}$ & $\begin{array}{l}-107.79 \\
(256.85)\end{array}$ & $\begin{array}{c}11.16 \\
(60.02)\end{array}$ & $\begin{array}{c}186.23 \\
(195.75)\end{array}$ & $\begin{array}{c}148.31 \\
(221.48)\end{array}$ \\
\hline Ethnic diversity of neighborhood & $\begin{array}{c}92.59 \\
(72.48)\end{array}$ & $\begin{array}{c}64.64 \\
(239.90)\end{array}$ & $\begin{array}{c}252.38 \\
(260.13)\end{array}$ & $\begin{array}{c}40.66 \\
(45.53)\end{array}$ & $\begin{array}{c}-50.24 \\
(200.45)\end{array}$ & $\begin{array}{c}-65.51 \\
(224.30)\end{array}$ \\
\hline Baseline covariates & Yes & Yes & Yes & Yes & Yes & Yes \\
\hline Mean dep var & $1,001.51$ & 896.39 & 914.20 & 35.28 & 60.57 & 56.79 \\
\hline Observations & 496 & 104 & 81 & 496 & 104 & 81 \\
\hline$R$-squared & 0.13 & 0.20 & 0.24 & 0.03 & 0.14 & 0.14 \\
\hline
\end{tabular}

\section{B. Geography}

Another possible source of bias are geographic differences between the historical Kuba Kingdom and the surrounding areas. In fact, Mary Douglas (1962, 1963) conjectures that potential differences in crop suitability across the Kasai river may partially explain differences between the Kuba and Lele. If geographic differences do in fact exist, and these factors had an independent effect on cultural evolution, then these may bias our estimates.

We examine this possibility using data from the FAO's GAEZ database on the agricultural suitability of land in our sample region for the cultivation of crops. The data are available for grid-cells that are 5 arc minutes by 5 arc minutes (approximately 6 miles by 6 miles). We consider the two staple crops in the region: maize and cassava. The suitability indices range from o to 100. Figures $6 \mathrm{a}$ and $6 \mathrm{~b}$ show these indices along with the origin villages for the participants in our sample. From the figures, the suitability for both crops appears similar inside and outside the Kuba Kingdom. We test this formally by measuring the suitability of the grid-cell of each participant's origin village. 


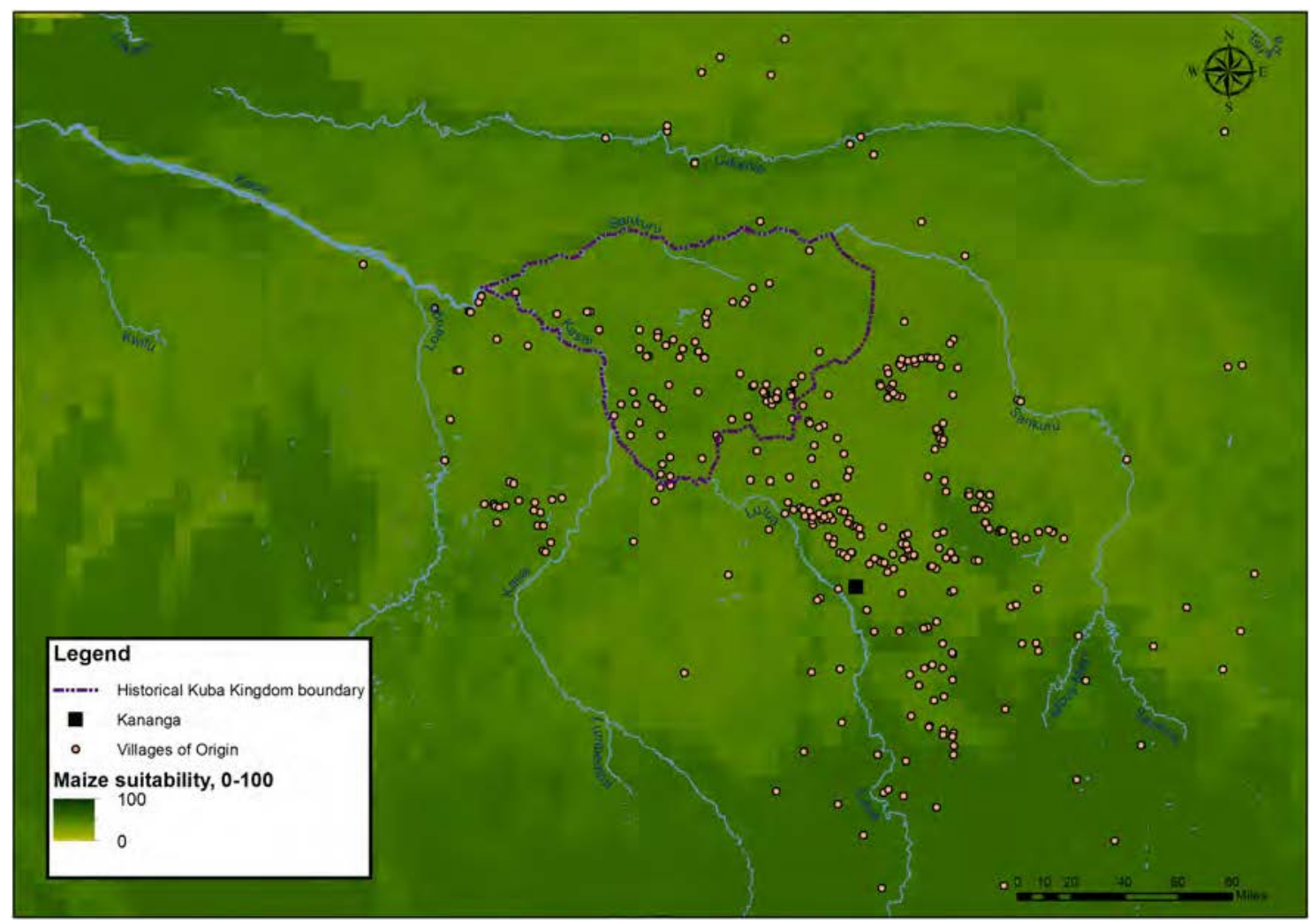

(a) Maize suitability index, 0-100.

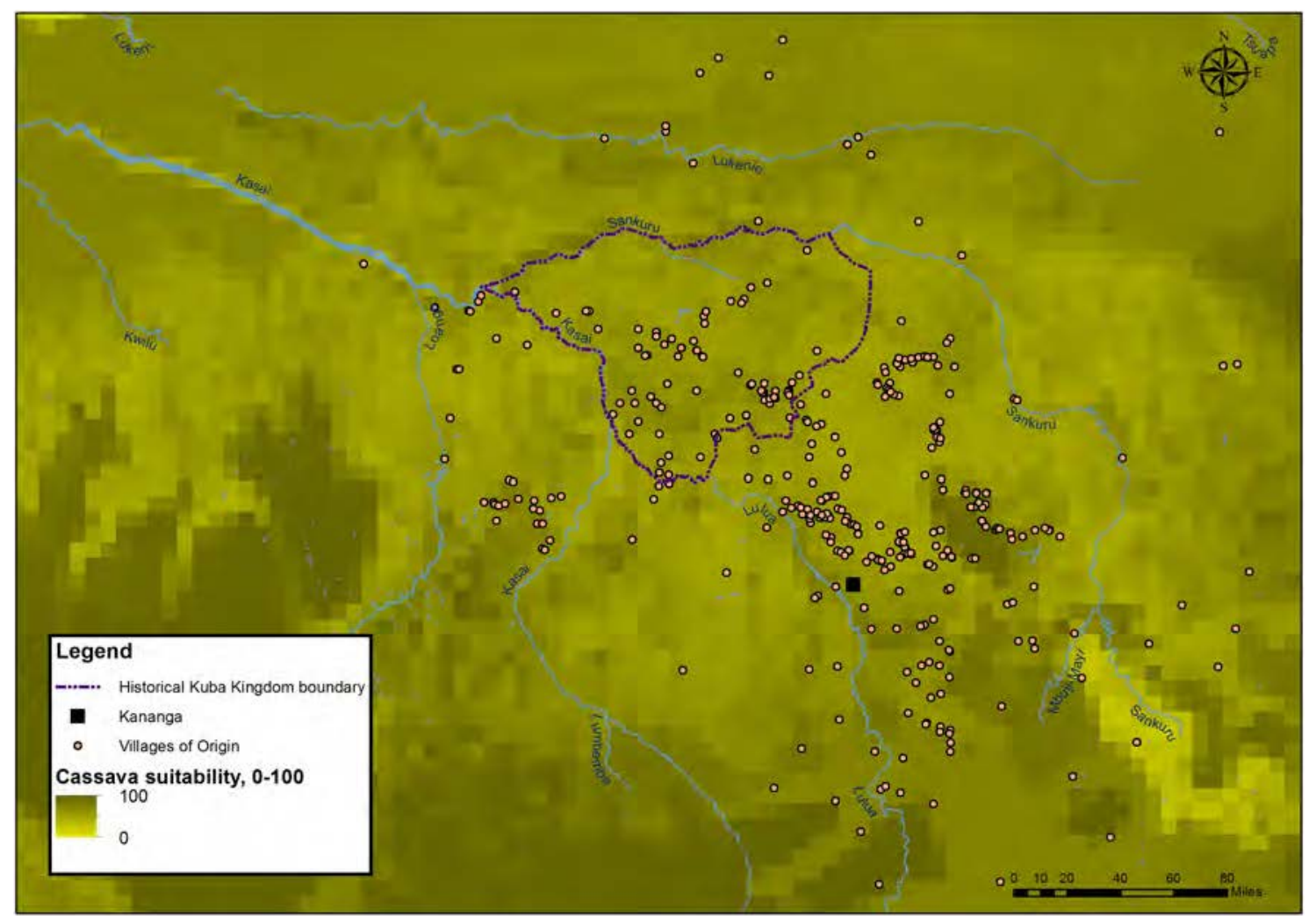

(b) Cassava suitability index, o-100.

Figure 6: FAO GAEZ crop suitability measures, maize and cassava. 
Table 5: Balance table: Crop suitability.

\begin{tabular}{|c|c|c|c|c|c|c|c|c|c|}
\hline & Kuba & Non-Kuba & Difference & $\begin{array}{c}\text { Central } \\
\text { Kuba } \\
\end{array}$ & Lele & Difference & Bushong & Lele & Difference \\
\hline Maize suitability & 22.89 & 23.14 & -0.25 & 23.00 & 23.16 & -0.16 & 23.08 & 23.16 & -0.08 \\
\hline \multirow[t]{2}{*}{ index, $0-100$} & $(0.12)$ & $(0.18)$ & $(0.22)$ & $(0.13)$ & $(0.60)$ & $(0.61)$ & $(0.14)$ & $(0.60)$ & $(0.61)$ \\
\hline & 80 & 419 & 499 & 61 & 44 & 105 & 38 & 44 & 82 \\
\hline Cassava suitability & 46.58 & 46.71 & -0.14 & 46.85 & 48.02 & -1.17 & 47.11 & 48.02 & -0.92 \\
\hline \multirow[t]{2}{*}{ index, $0-100$} & $(0.38)$ & $(0.41)$ & $(0.55)$ & $(0.43)$ & $(1.45)$ & $(1.51)$ & $(0.48)$ & $(1.45)$ & $(1.53)$ \\
\hline & 80 & 419 & 499 & 61 & 44 & 105 & 38 & 44 & 82 \\
\hline
\end{tabular}

A balance table showing the mean of these measures for Kuba and non-Kuba descendants, and their difference, appears in table 5. The table shows no differences between Kuba and non-Kuba observations for all three samples. While the average maize suitability in the sample is approximately 23 (of 100), the average difference between the Kuba and non-Kuba observations range from 0.08 to 0.25 . For cassava suitability, the mean suitability measure is higher at around 47, while the gap only ranges from 0.14 to 1.17. In addition, none of these differences is statistically significant. ${ }^{36}$

\section{Examining Causal Channels}

We now turn to an examination of other potential channels and alternative interpretations of our finding of greater cheating among Kuba descendants.

\section{A. Income and Prosperity}

A potential mechanism underlying the effects we find is the greater historical prosperity of the Kuba Kingdom. The historical formation of states in sub-Saharan Africa is on average associated with greater economic activity today (Gennaioli and Rainer, 2007, Michalopoulos and Papaioannou, 2013, 2104). This might also be one of the legacies of the Kuba state. Historically, the Kuba Kingdom facilitated trade, specialization of production, agricultural productivity, technological

\footnotetext{
${ }^{36}$ As shown in appendix table A5, our estimates of equation (1) are robust to the inclusion of these controls. Although the standard errors increase slightly, the point estimates remain nearly identical to the baseline estimates.
} 
Table 6: Testing for differences in income and prosperity.

\begin{tabular}{|c|c|c|c|c|}
\hline & $\begin{array}{c}\text { Subjective income } \\
\text { scale, } 1-5 \\
\end{array}$ & ln Annual income & ln Monthly income & $\begin{array}{c}\text { Unemployment } \\
\text { indicator }\end{array}$ \\
\hline & $(1)$ & $(2)$ & $(3)$ & $(4)$ \\
\hline & \multicolumn{4}{|c|}{ Panel A. Full sample } \\
\hline \multirow[t]{2}{*}{ Kuba ethnicity indicator } & $0.188^{*}$ & 0.207 & 0.152 & -0.046 \\
\hline & $(0.103)$ & $(0.289)$ & $(0.247)$ & $(0.056)$ \\
\hline Observations & 499 & 499 & 499 & 499 \\
\hline Mean dep var & 2.16 & 13.05 & 10.74 & 0.63 \\
\hline \multirow[t]{2}{*}{ R squared } & 0.059 & 0.038 & 0.037 & 0.130 \\
\hline & \multicolumn{4}{|c|}{ Panel B. Central Kuba \& Lele } \\
\hline \multirow[t]{2}{*}{ Kuba ethnicity indicator } & 0.020 & -0.308 & -0.086 & $-0.141^{*}$ \\
\hline & $(0.178)$ & $(0.579)$ & $(0.483)$ & $(0.082)$ \\
\hline Observations & 105 & 105 & 105 & 105 \\
\hline Mean dep var & 2.26 & 13.17 & 10.70 & 0.657 \\
\hline \multirow[t]{2}{*}{ R squared } & 0.03 & 0.04 & 0.05 & 0.33 \\
\hline & \multicolumn{4}{|c|}{ Panel C. Bushong \& Lele } \\
\hline \multirow[t]{2}{*}{ Kuba ethnicity indicator } & -0.009 & -0.353 & -0.178 & -0.148 \\
\hline & $(0.206)$ & $(0.652)$ & $(0.541)$ & $(0.090)$ \\
\hline Observations & 82 & 82 & 82 & 82 \\
\hline Mean dep var & 2.22 & 13.15 & 10.66 & 0.671 \\
\hline$R$-squared & 0.05 & 0.04 & 0.04 & 0.36 \\
\hline
\end{tabular}

Notes: The table reports OLS estimates of equation (1) with measures of income as the dependent variable.

"Kuba ethnicity indicator" is a variable that equals one if the individual's self reported tribe is Kuba. All regressions control for a gender indicator, age, age squared, and a survey year fixed effect. *, **, and *** indicate significance at the 10,5 , and $1 \%$ levels.

innovation, and a higher standard of living. If income differences persist until today, they might be an important channel that explains the differences in rule-following that we observe. ${ }^{37}$

We examine this potential channel by first checking for income differences between Kuba and non-Kuba descendants. We re-estimate equation (1), substituting various measures of income and prosperity as the dependent variable. ${ }^{38}$ Estimates are reported in table 6. Since income is noisy and difficult to measure in resource-poor settings, our strategy is to examine a variety of different measures.

Our first measure is an index of individuals' perceived income status. Respondents were asked to imagine a scale from 1 to 5 , where 1 is the poorest level on the scale and 5 is the richest. They are then asked to report the level at which they are situated relative to other people in Kananga.

\footnotetext{
37This possibility is particularly important given evidence that being from a higher social class is associated with more unethical behavior (Piff et al., 2012), and that the physical presence of money causes individuals to behave more unethically (Gino and Pierce, 2009).

${ }^{38}$ Alternatively, we could have produced a balance table that shows difference between the two groups without conditioning on our baseline covariates. Doing this yields very similar results. We prefer to condition on our baseline covariates because it is highly likely that age and gender are important determinants of income.
} 
This scale could be interpreted as capturing either income or wealth. Estimates using the 1-5 scale are reported in column 1 . We also directly measure an individual's earned income, over the past year and over the past month (both measured in Congolese Francs). While the annual measure has the advantage of providing an income estimate over a longer period of time, recall over a full year may be less accurate than that for the past month. Estimates using these measures are reported in columns 2 and 3. The last measure is an individual's current employment status (results reported in column 4). Although this measure is coarse, it has the benefit of being known with certainty and therefore accurately reported.

The results provide weak evidence that Kuba descendants might be slightly more prosperous relative to other groups. In the full sample (panel A), the self-reported income scale is higher for Kuba descendants (column 1), although this difference disappears in the restricted samples (panels B and C). In all three panels, we find no statistical difference in self-reported income over the past year or over the past month (columns 2 and 3). However, we find that the Kuba appear less likely to be unemployed (column 4). In the restricted samples (panels B and C), the Kuba are about 15 percentage points less likely to be unemployed.

We explore this channel further by re-estimating equation (1) while controlling for these four measures of income. Estimates, reported in table 7, show that higher frequency of rule breaking and theft among the Kuba is robust to controlling for available measures of income. The income channel does not appear to explain our main results.

\section{B. The Colonial Period}

Another potential explanation for the greater propensity of Kuba descendants to break the rules is that they were treated differently during the colonial period. It is possible that because of the Kingdom's pre-existing formal institutions, the Belgian colonists treated the Kuba differently than they treated other groups. This in turn could have affected beliefs and behaviors concerning following the rules.

We explore this mechanism by measuring colonial investments and missionary activity. The measures are taken from Mantnieks (1951), who reports the location of mission stations, electricity stations, railroads, and mines. Figures $7 \mathrm{a}$ and $7 \mathrm{~b}$ show the locations of these colonial investments (as of 1951), as well as the Kuba boundary. 


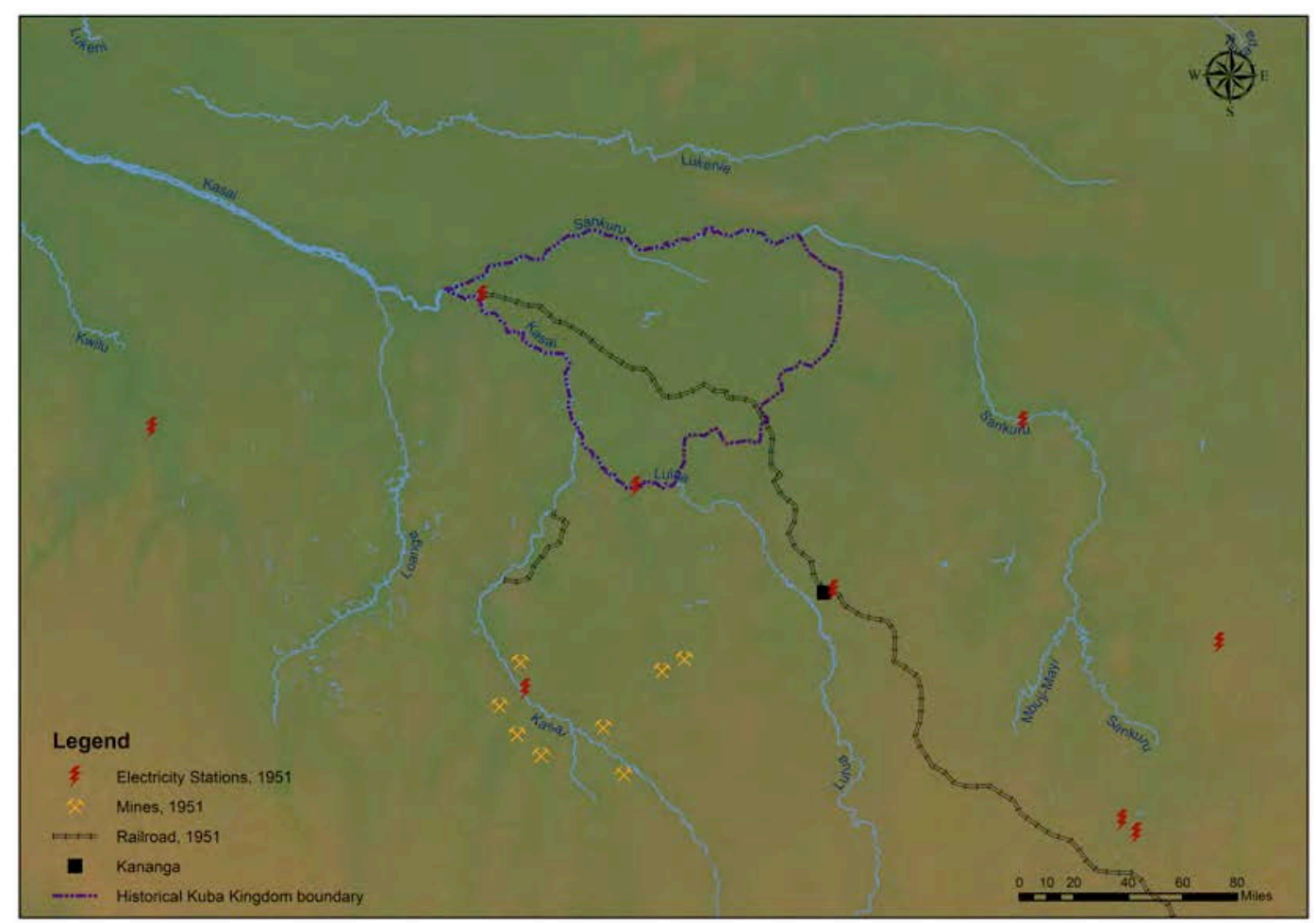

(a) Colonial infrastructure: Power stations, railways, and mines

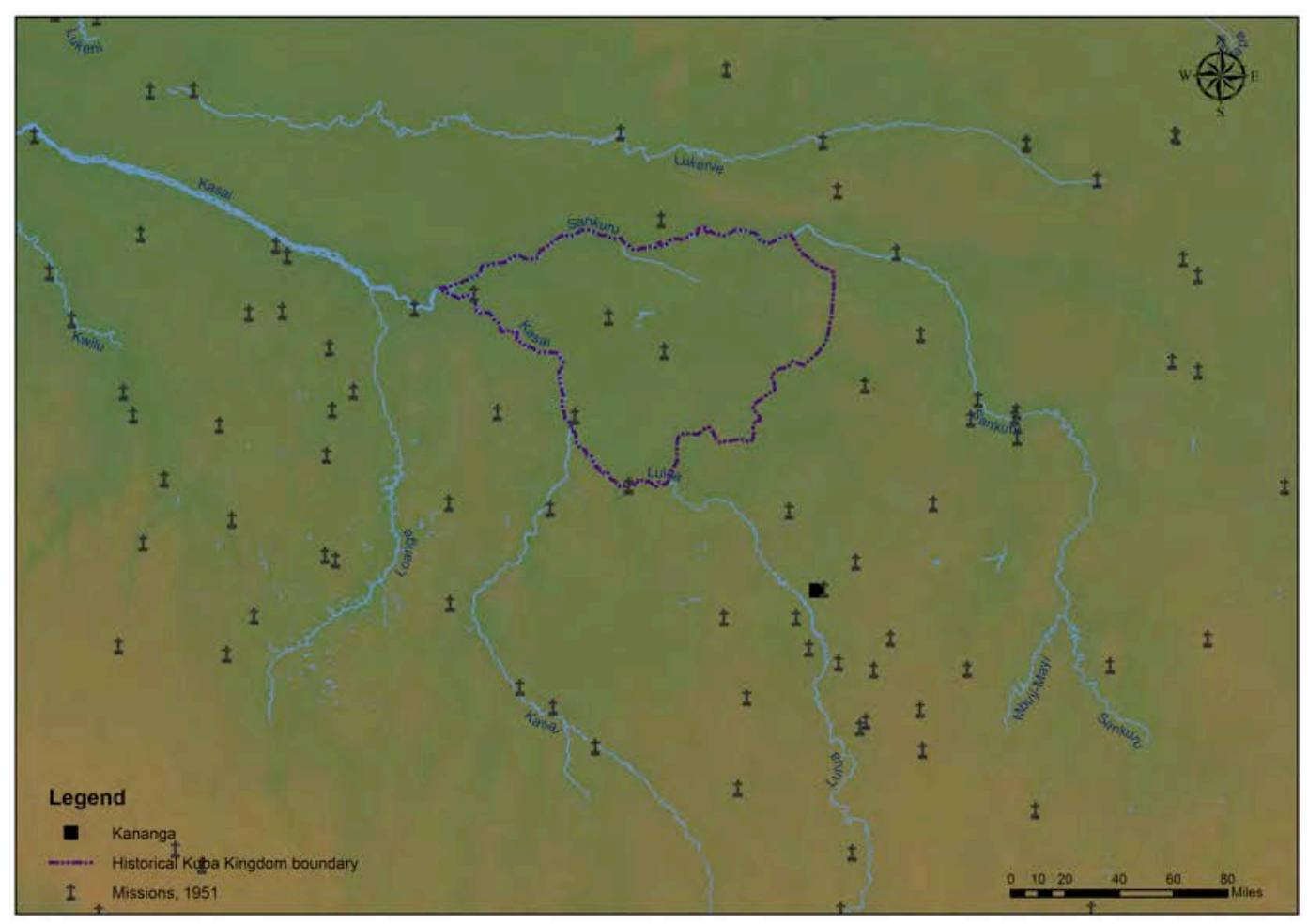

(b) Mission stations.

Figure 7: Measures of colonial rule and missionary activity. 
Table 7: Accounting for income and prosperity.

\begin{tabular}{|c|c|c|c|c|c|c|}
\hline & \multicolumn{3}{|c|}{$\begin{array}{l}\text { Average amount allocated to other party (of } \\
3000 \mathrm{CF} \text { ) in the RAG: }\end{array}$} & \multicolumn{3}{|c|}{ Amount of money missing in UG } \\
\hline & $\begin{array}{c}\text { Kuba vs. all } \\
\text { others }\end{array}$ & $\begin{array}{l}\text { Central Kuba } \\
\text { vs. Lele }\end{array}$ & $\begin{array}{l}\text { Bushong vs. } \\
\text { Lele }\end{array}$ & $\begin{array}{c}\text { Kuba vs. all } \\
\text { others }\end{array}$ & $\begin{array}{c}\text { Central Kuba } \\
\text { vs. Lele }\end{array}$ & $\begin{array}{c}\text { Bushong vs. } \\
\text { Lele }\end{array}$ \\
\hline & $(1)$ & $(2)$ & (3) & $(4)$ & (5) & (6) \\
\hline Kuba ethnicity indicator & $\begin{array}{l}-95.57^{* *} \\
(41.53)\end{array}$ & $\begin{array}{c}-177.31^{* *} \\
(72.75)\end{array}$ & $\begin{array}{c}-241.02^{* * *} \\
(80.67)\end{array}$ & $\begin{array}{l}57.79 * * \\
(25.51)\end{array}$ & $\begin{array}{l}143.55^{* *} \\
(61.25)\end{array}$ & $\begin{array}{l}152.21^{* *} \\
(72.78)\end{array}$ \\
\hline \multicolumn{7}{|l|}{ Income controls: } \\
\hline Subjective income scale & $\begin{array}{l}32.60^{*} \\
(18.24)\end{array}$ & $\begin{array}{c}19.24 \\
(42.67)\end{array}$ & $\begin{array}{c}70.61 \\
(45.89)\end{array}$ & $\begin{array}{c}-4.61 \\
(11.20)\end{array}$ & $\begin{array}{c}-0.44 \\
(35.92)\end{array}$ & $\begin{array}{l}-13.45 \\
(41.40)\end{array}$ \\
\hline ln Annual income & $\begin{array}{c}9.65 \\
(11.37)\end{array}$ & $\begin{array}{c}13.27 \\
(17.28)\end{array}$ & $\begin{array}{c}7.18 \\
(17.59)\end{array}$ & $\begin{array}{c}0.45 \\
(6.99)\end{array}$ & $\begin{array}{c}8.39 \\
(14.55)\end{array}$ & $\begin{array}{c}7.92 \\
(15.87)\end{array}$ \\
\hline ln Monthly income & $\begin{array}{l}-12.85 \\
(13.29)\end{array}$ & $\begin{array}{l}-20.05 \\
(20.42)\end{array}$ & $\begin{array}{l}-25.27 \\
(20.85)\end{array}$ & $\begin{array}{c}3.43 \\
(8.16)\end{array}$ & $\begin{array}{c}6.13 \\
(17.19)\end{array}$ & $\begin{array}{c}5.08 \\
(18.81)\end{array}$ \\
\hline Unemployment indicator & $\begin{array}{c}-19.93 \\
(33.63)\end{array}$ & $\begin{array}{c}-98.92 \\
(93.60)\end{array}$ & $\begin{array}{l}-201.69 * \\
(107.75)\end{array}$ & $\begin{array}{l}-15.22 \\
(20.65)\end{array}$ & $\begin{array}{c}1.39 \\
(78.80)\end{array}$ & $\begin{array}{l}-14.02 \\
(97.20)\end{array}$ \\
\hline Baseline covariates & Yes & Yes & Yes & Yes & Yes & Yes \\
\hline Mean dep var & $1,001.75$ & 895.24 & 912.50 & 35.07 & 60.00 & 56.10 \\
\hline Observations & 499 & 105 & 82 & 499 & 105 & 82 \\
\hline$R$-squared & 0.09 & 0.18 & 0.27 & 0.02 & 0.10 & 0.09 \\
\hline
\end{tabular}

Using digitized data from Mantnieks (1951), we construct indicator variables that equal one if any of these colonial investments were located within 30 kilometers of an individual's origin village. The differences in the means of the measures across Kuba and non-Kuba observations are reported in table 8 . Kuba ancestors were less likely to be near a power station, but more likely to have been near a railway line. Both of these differences are significant and exist in each of the three samples. We do not see any significant difference in proximity to missions or mines.

Motivated by these differences, we re-estimate equation (1) with the colonial control variables, clustering standard errors at the village level. The estimates, reported in table 9, show that our reduced-form Kuba effect remains robust to the inclusion of the set of the colonial control variables. Although the standard errors increase slightly, comparing the estimates of table 9 with the baseline estimates of table 2, the point estimates are stable. In four of the six specifications, the magnitude of the Kuba effect actually increases after controlling for the colonial covariates. This suggests that it is unlikely that the effect we find is working through differential colonial 
Table 8: Balance table: Colonial contact.

\begin{tabular}{|c|c|c|c|c|c|c|c|c|c|}
\hline & Kuba & Non-Kuba & Difference & $\begin{array}{c}\text { Central } \\
\text { Kuba }\end{array}$ & Lele & Difference & Bushong & Lele & Difference \\
\hline \multirow[t]{2}{*}{ Mission station } & $\begin{array}{c}0.675 \\
(0.068)\end{array}$ & $\begin{array}{c}0.766 \\
(0.024)\end{array}$ & $\begin{array}{c}-0.091 \\
(0.071)\end{array}$ & $\begin{array}{c}0.770 \\
(0.065)\end{array}$ & $\begin{array}{c}0.795 \\
(0.066)\end{array}$ & $\begin{array}{l}-0.025 \\
(0.093)\end{array}$ & $\begin{array}{c}0.921 \\
(0.044)\end{array}$ & $\begin{array}{c}0.795 \\
(0.066)\end{array}$ & $\begin{array}{c}0.126 \\
(0.081)\end{array}$ \\
\hline & 80 & 419 & 499 & 61 & 44 & 105 & 38 & 44 & 82 \\
\hline \multirow[t]{2}{*}{ Power station } & $\begin{array}{c}0.025 \\
(0.018)\end{array}$ & $\begin{array}{c}0.115 \\
(0.019)\end{array}$ & $\begin{array}{c}-0.090^{* * *} \\
(0.026)\end{array}$ & $\begin{array}{l}0.000 \\
(0.000)\end{array}$ & $\begin{array}{c}0.182 \\
(0.077)\end{array}$ & $\begin{array}{c}-0.182^{* *} \\
(0.077)\end{array}$ & $\begin{array}{l}0.000 \\
(0.000)\end{array}$ & $\begin{array}{c}0.182 \\
(0.077)\end{array}$ & $\begin{array}{c}-0.182^{* *} \\
(0.077)\end{array}$ \\
\hline & 80 & 419 & 499 & 61 & 44 & 105 & 38 & 44 & 82 \\
\hline \multirow[t]{2}{*}{ Railway line } & $\begin{array}{c}0.775 \\
(0.057)\end{array}$ & $\begin{array}{c}0.499 \\
(0.031)\end{array}$ & $\begin{array}{c}0.276^{* * *} \\
(0.064)\end{array}$ & $\begin{array}{c}0.902 \\
(0.047)\end{array}$ & $\begin{array}{c}0.477 \\
(0.096)\end{array}$ & $\begin{array}{c}0.424^{* * *} \\
(0.106)\end{array}$ & $\begin{array}{c}0.895 \\
(0.065)\end{array}$ & $\begin{array}{c}0.477 \\
(0.096)\end{array}$ & $\begin{array}{c}0.417^{* * *} \\
(0.115)\end{array}$ \\
\hline & 80 & 419 & 499 & 61 & 44 & 105 & 38 & 44 & 82 \\
\hline \multirow[t]{2}{*}{ Mines } & $\begin{array}{c}0.000 \\
(0.000)\end{array}$ & $\begin{array}{c}0.002 \\
(0.002)\end{array}$ & $\begin{array}{c}-0.002 \\
(0.002)\end{array}$ & $\begin{array}{c}0.000 \\
(0.000)\end{array}$ & $\begin{array}{c}0.000 \\
(0.000)\end{array}$ & $\begin{array}{c}0.000 \\
(0.000)\end{array}$ & $\begin{array}{c}0.000 \\
(0.000)\end{array}$ & $\begin{array}{c}0.000 \\
(0.000)\end{array}$ & $\begin{array}{c}0.000 \\
(0.000)\end{array}$ \\
\hline & 80 & 419 & 499 & 61 & 44 & 105 & 38 & 44 & 82 \\
\hline
\end{tabular}

Notes: The table reports balance statistics for indicator variables that measure whether an ancestral village was within 30 kilometers of a particular colonial infrastructure in 1951. An observation is an individual in our sample. The statistics are reported for each of our three samples of interest.

contact.

Among the forms of European influence during the colonial period, missions and religious conversion is a particularly important potential channel. Previous research has shown that missions in Africa had a long-term impact on religiosity (Nunn, 2010), which in turn might affect individuals' propensity to break rules and steal. If, for example, descendants of the Kuba are less religious, they might have a weaker spiritual interdiction against breaking rules. To examine this issue, we use respondents' answers to survey questions to construct composite measures of the strength of Christian beliefs and of traditional beliefs. (These measures are described in detail in section A6 of the online appendix.) According to these measures, however, there are no differences in religiosity between Kuba and non-Kuba descendants. Further, controlling for religiosity does not affect our baseline estimate (see appendix tables A9 and A10).

\section{The Post-Colonial Period}

The Kuba might also have been treated systematically differently by the government of President Joseph Mobutu Sese-Seko during the post-colonial period, which could explain the experimental differences that we observe today. Since there is little available data from this period, we focus on self-reported attitudes of President Mobutu, which should capture unobserved impacts of the 
Table 9: Accounting for colonial contact.

\begin{tabular}{|c|c|c|c|c|c|c|}
\hline & \multicolumn{3}{|c|}{$\begin{array}{l}\text { Average amount allocated to other party (of } \\
3000 \mathrm{CF} \text { ) in the RAG: }\end{array}$} & \multicolumn{3}{|c|}{ Amount of money missing in UG } \\
\hline & $\begin{array}{c}\text { Kuba vs. all } \\
\text { others }\end{array}$ & $\begin{array}{l}\text { Central Kuba } \\
\text { vs. Lele }\end{array}$ & $\begin{array}{l}\text { Bushong vs. } \\
\text { Lele }\end{array}$ & $\begin{array}{c}\text { Kuba vs. all } \\
\text { others }\end{array}$ & $\begin{array}{l}\text { Central Kuba } \\
\text { vs. Lele }\end{array}$ & $\begin{array}{l}\text { Bushong vs. } \\
\text { Lele }\end{array}$ \\
\hline & $(1)$ & $(2)$ & (3) & $(4)$ & (5) & $(6)$ \\
\hline Kuba ethnicity indicator & $\begin{array}{c}-103.25^{* *} \\
(48.90)\end{array}$ & $\begin{array}{l}-198.53^{*} \\
(109.34)\end{array}$ & $\begin{array}{l}-253.64^{*} \\
(139.40)\end{array}$ & $\begin{array}{c}51.00 \\
(34.17)\end{array}$ & $\begin{array}{c}134.54^{* *} \\
(62.30)\end{array}$ & $\begin{array}{l}164.74^{*} \\
(90.67)\end{array}$ \\
\hline \multicolumn{7}{|c|}{ Colonial indicators (within $30 \mathrm{~km}$ in 1951): } \\
\hline Mission station & $\begin{array}{c}5.49 \\
(36.08)\end{array}$ & $\begin{array}{l}-99.57 \\
(85.21)\end{array}$ & $\begin{array}{c}22.74 \\
(124.57)\end{array}$ & $\begin{array}{c}18.07 \\
(17.34)\end{array}$ & $\begin{array}{c}-80.95 \\
(74.80)\end{array}$ & $\begin{array}{l}-109.67 \\
(80.30)\end{array}$ \\
\hline Power station & $\begin{array}{c}0.46 \\
(52.73)\end{array}$ & $\begin{array}{c}-223.96 \\
(166.14)\end{array}$ & $\begin{array}{c}-266.83 \\
(175.16)\end{array}$ & $\begin{array}{c}-26.74 \\
(20.55)\end{array}$ & $\begin{array}{c}20.40 \\
(34.22)\end{array}$ & $\begin{array}{c}31.87 \\
(40.18)\end{array}$ \\
\hline Railway line & $\begin{array}{l}57.56^{*} \\
(32.25)\end{array}$ & $\begin{array}{c}-16.04 \\
(122.93)\end{array}$ & $\begin{array}{c}-23.54 \\
(144.43)\end{array}$ & $\begin{array}{c}25.71 \\
(16.15)\end{array}$ & $\begin{array}{c}26.76 \\
(33.08)\end{array}$ & $\begin{array}{c}25.69 \\
(39.61)\end{array}$ \\
\hline Mine & $\begin{array}{l}-82.57 * \\
(44.46)\end{array}$ & & & $\begin{array}{c}38.99 * \\
(23.00)\end{array}$ & & \\
\hline Baseline covariates & Yes & Yes & Yes & Yes & Yes & Yes \\
\hline Mean dep var & $1,001.75$ & 895.24 & 912.50 & 35.07 & 60.00 & 56.09 \\
\hline Observations & 499 & 105 & 82 & 499 & 105 & 82 \\
\hline$R$-squared & 0.09 & 0.20 & 0.22 & 0.03 & 0.10 & 0.10 \\
\hline
\end{tabular}

Mobutu regime. If the regime treated locations in systematically different ways, this will likely be reflected in individuals' attitudes towards the regime.

We collected two survey-based measures of attitudes towards Mobutu. First, we asked respondents to report their view of former President Mobutu, choosing between: very positive, somewhat positive, neutral, somewhat negative, and very negative. We also asked respondents their view of the overall impacts of Mobutu, using the same scale.

Because participants might be unwilling to answer truthfully questions about potentially sensitive political figures, we also measured individuals' attitudes towards former President Mobutu using a single-target implicit association test (ST-IAT). The test was recently developed by Bluemke and Friese (2008). It is a variant of the original IAT and is intended to measure the positivity or negativity of individuals' implicit association of a single target (which in our case is Mobutu). 39

\footnotetext{
${ }^{39}$ Elsewhere, we have used the single-target IAT to examine individual attitudes towards other ethnic groups (Lowes, Nunn, Robinson and Weigel, 2015). The paper also describes a test of the IAT's validity in this setting using ST-IATs with food, spiders, and snakes as targets. Consistent with expectations, the ST-IAT scores indicated that participants view food very positively and spiders and snakes negatively. See section $\mathrm{A}_{3}$ of the appendix for more details.
} 
The IATs were played on ten-inch Samsung Galaxy Tab III tablets. During the IAT, participants are asked to sort images into two groups, one group on the left side and one group on the right side. Three different types of images appear on the screen of a tablet: images of happy people, images of sad people, and images of Mobutu. The sorting is done by pressing a button on the lower left or the lower right of the tablet's touch screen. Screen shots from the IAT, showing the buttons at the bottom left and bottom right of the screen as well as the image in the center of the screen, are provided in figure 8.

The IAT has two blocks, in both of which happy images are sorted to the left and sad images are sorted to the right. In one block, images of President Mobutu are sorted to the same side as the happy images (left), and in the other block, images of Mobutu are sorted to the same side as the sad images (right). The order of the blocks is randomized across individuals. During the activity, the sides that the images are to be sorted to are indicated by small anchor images on the top left and top right. These are also visible in the screenshots shown in figure 8. Figures 8a-8c show screenshots for the block with Mobutu sorted to the same side as the sad images (right), while figures $8 \mathrm{~d}-8 \mathrm{f}$ show screenshots for the block with Mobutu sorted to the same side as the happy images (left).

The logic of the ST-IAT is as follows. If a participant has a positive view of Mobutu, then sorting will be faster when the participant has to sort Mobutu images and happy images to the left and sad images to the right. Subconsciously, they can exploit the heuristic: 'good things to the left bad things to the right'. If the participant has a negative view of Mobutu, then this heuristic does not apply. Instead, sorting will be quicker when the Mobutu images are sorted to the same side of the screen as the sad images (right). Then the heuristic is: 'good things to the left and bad things to the right'. Again, this heuristic is not effective if Mobutu is viewed positively. By comparing the speed at which the participant sorts images during the two blocks, we can infer their implicit view of Mobutu. $4^{\circ}$

From the ST-IAT we calculate the standard $D$-score, which is defined as:

$$
\left.D \text {-score }=\left[\text { Mean }\left(\text { latency }^{-v e}\right)-\text { Mean }_{\left(\text {latency }^{+v e}\right)}\right)\right] / S D\left(\text { latency }^{\text {both }}\right)
$$

where $M e a n\left(\right.$ latency $\left.^{-v e}\right)$ is the recorded average response time (measured in milliseconds) for the block in which the Mobutu images are sorted to the same side as sad images, Mean(latency ${ }^{+v e}$ )

$4^{\circ}$ The finer details of the ST-IAT are provided in the paper's online appendix. 


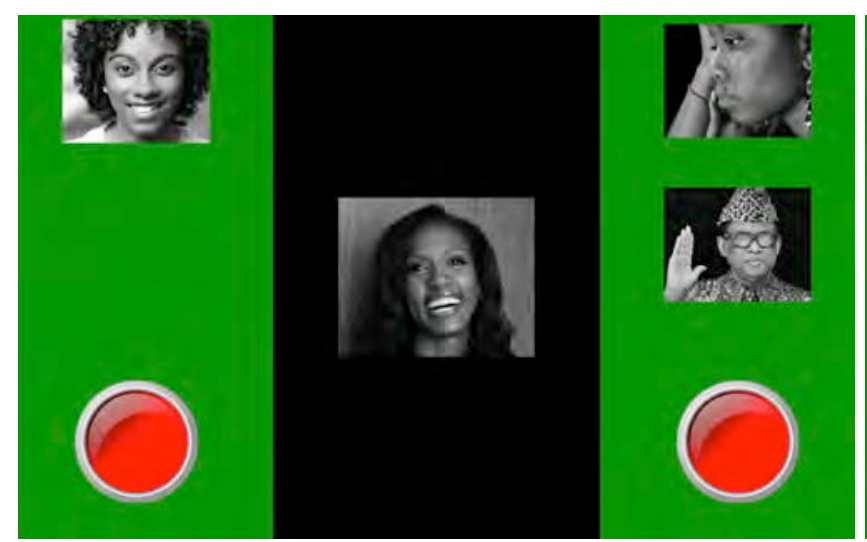

(a) Happy image: sort left.

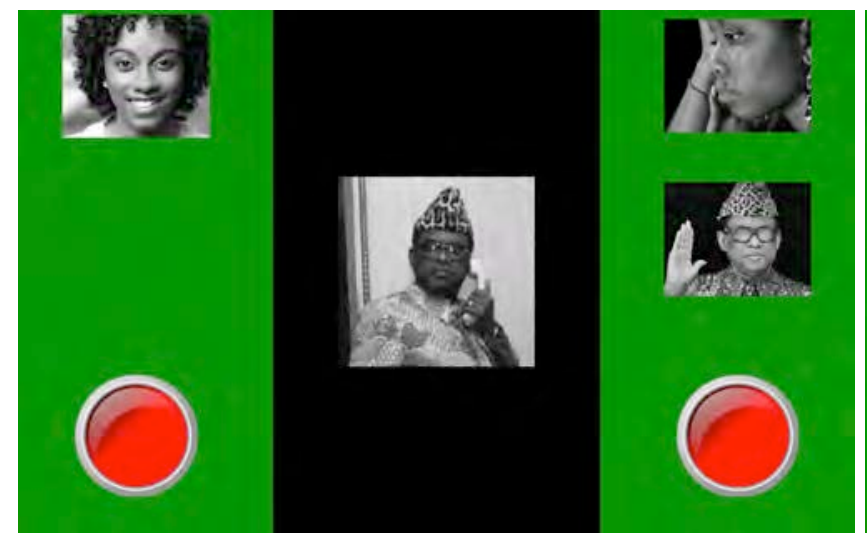

(c) Mobutu: sort right.

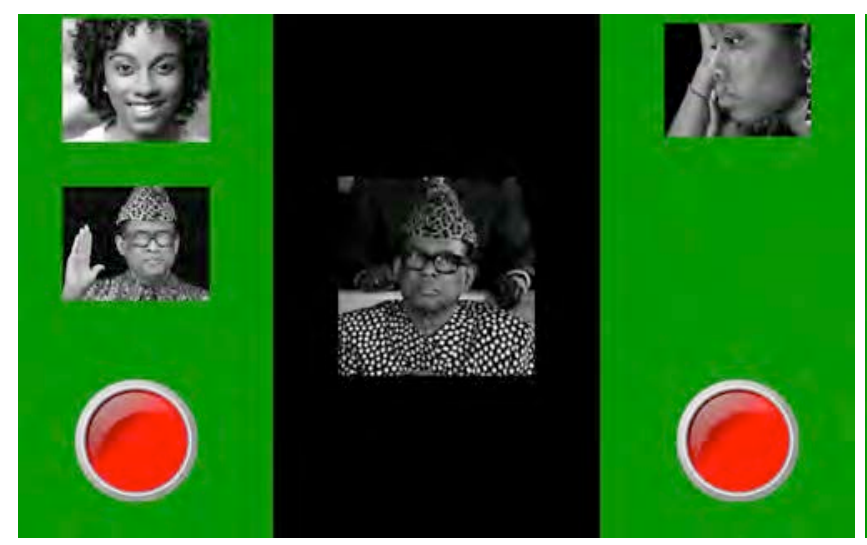

(e) Mobutu: sort left.

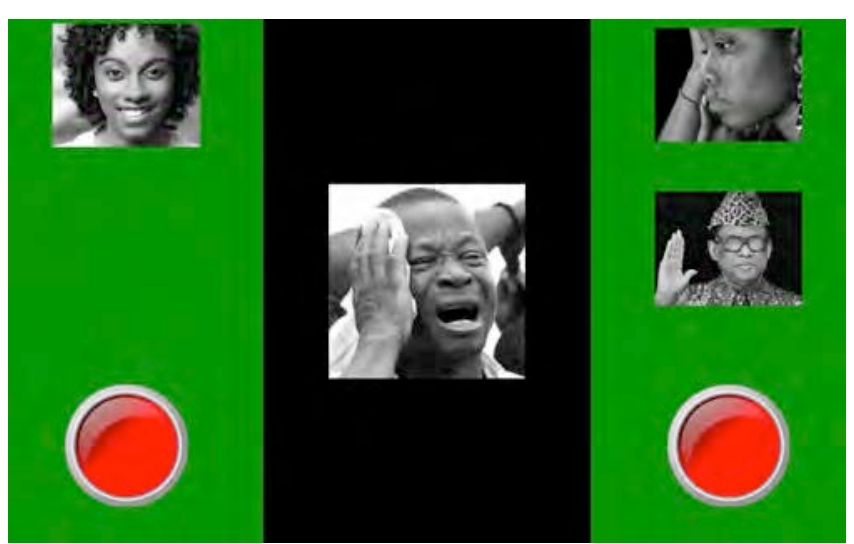

(b) Sad image: sort right.

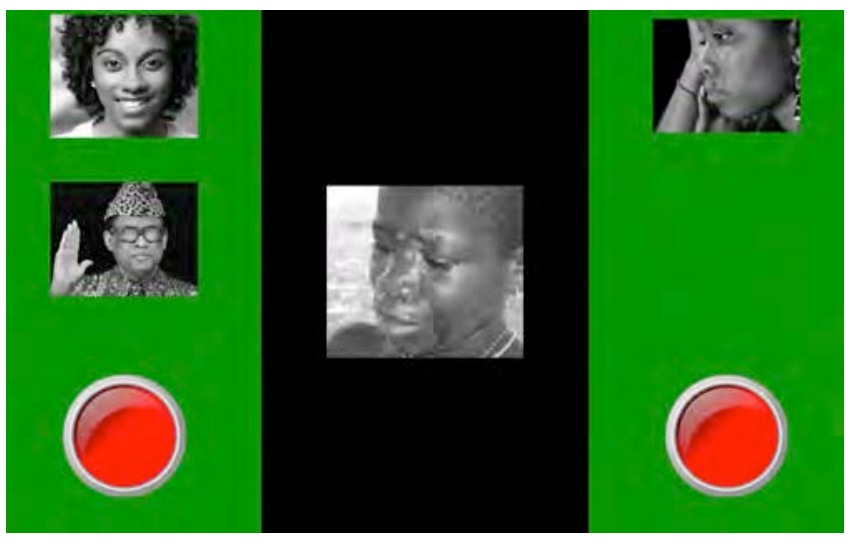

(d) Sad image: sort right.

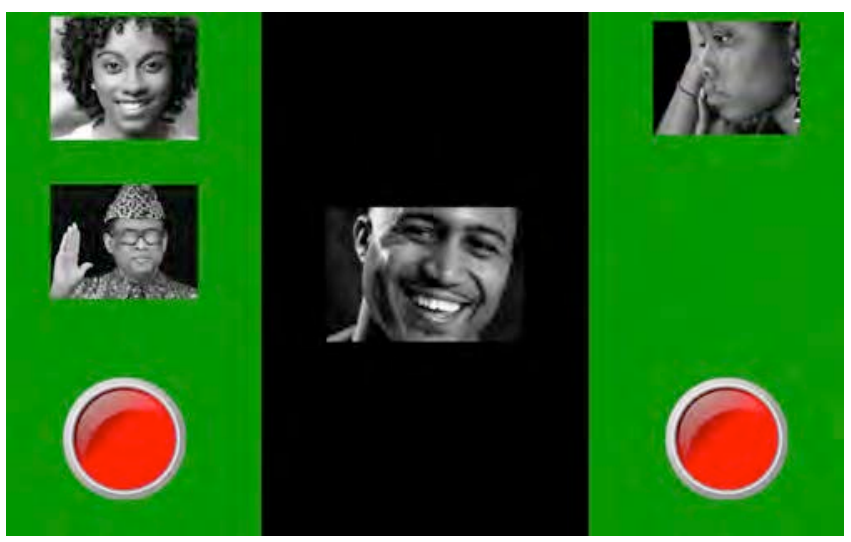

(f) Happy image: sort left.

Figure 8: Screen shots from Mobutu IAT on a tablet. 
Table 10: Testing for differences in attitudes towards President Mobutu.

\begin{tabular}{|c|c|c|c|}
\hline & $\begin{array}{l}\text { Impact of Mobutu, 1- } \\
5 \text { scale }\end{array}$ & $\begin{array}{c}\text { Perception of } \\
\text { Mobutu, 1-5 scale } \\
\end{array}$ & $\begin{array}{l}\text { Mobutu ST-IAT D- } \\
\text { Score } \\
\end{array}$ \\
\hline & $(1)$ & $(2)$ & $(3)$ \\
\hline & \multicolumn{3}{|c|}{ Panel A. Full sample } \\
\hline \multirow[t]{2}{*}{ Kuba ethnicity indicator } & -0.043 & 0.026 & -0.082 \\
\hline & $(0.146)$ & $(0.161)$ & $(0.061)$ \\
\hline Observations & 465 & 464 & 465 \\
\hline Mean dep var & 4.09 & 3.89 & 0.10 \\
\hline \multirow[t]{2}{*}{ R squared } & 0.034 & 0.033 & 0.014 \\
\hline & \multicolumn{3}{|c|}{ Panel B. Central Kuba \& Lele } \\
\hline \multirow[t]{2}{*}{ Kuba ethnicity indicator } & -0.018 & 0.414 & -0.056 \\
\hline & $(0.272)$ & $(0.305)$ & $(0.097)$ \\
\hline Observations & 93 & 93 & 93 \\
\hline Mean dep var & 3.86 & 3.57 & 0.16 \\
\hline \multirow[t]{2}{*}{ R squared } & 0.039 & 0.060 & 0.092 \\
\hline & \multicolumn{3}{|c|}{ Panel C. Bushong \& Lele } \\
\hline \multirow[t]{2}{*}{ Kuba ethnicity indicator } & -0.032 & $0.562^{*}$ & 0.002 \\
\hline & $(0.314)$ & $(0.335)$ & $(0.113)$ \\
\hline Observations & 71 & 71 & 71 \\
\hline Mean dep var & 3.86 & 3.61 & 0.19 \\
\hline$R$-squared & 0.084 & 0.138 & 0.135 \\
\hline
\end{tabular}

is the average response time for the block in which Mobutu images are sorted to the same side as happy images, and $S D\left(\right.$ latency $\left.y^{\text {both }}\right)$ is the standard deviation of the response time across both blocks. The constructed $D$-score is increasing in the positivity of the participant's view of Mobutu.

With our three measures of individuals' perception of Mobutu, we test whether there is evidence that Kuba descendants have a different view of Mobutu than non-Kuba descendants. The estimates are reported in table $10.4^{1}$ In all but one of the nine specifications, the coefficient on the Kuba ethnicity indicator variable is statistically insignificant. Not surprisingly, if we re-estimate our baseline equation (1) while controlling for these covariates, we obtain qualitatively identical estimates (see appendix table A6). Thus, the evidence suggests that the reduced-form Kuba effect is not due to differential treatment of the Kuba in the post-colonial period.

$4^{41}$ Note that we are missing IAT information for a number of observations. This is because the IAT was implemented for the first time in 2014. Therefore, some individuals from the 2013 sample could not be located again in 2014. 


\section{Other Cultural Characteristics}

\section{a. Trust in foreign researchers}

Another factor potentially affecting behavior in our experiments is participants' trust of our research team. Although our enumerators themselves all hailed from Kananga, participants were aware that the survey and experiments were conducted by researchers from Harvard University. Their actions in the RAG might have been affected, for example, by the extent to which they trusted that we really would give the amount allocated to the other party in the RAG and UG as we said we would (and in fact did).

We measure participants' self-reported trust in universities, in international organizations, and in people from other countries. When asked their level of trust, respondents chose between: not at all, not very much, somewhat, and completely. We assign integer values of $1,2,3$, and 4 , to the responses so that the constructed variables are increasing in reported trust.

Estimates of equation (1) with the trust measures as dependent variables are reported in table 11. As shown, we do not find strong evidence that the Kuba are less trusting. Although most coefficients are negative (8 of the 9), their magnitudes are small, and all estimates are statistically insignificant.

Nonetheless, we further check the trust channel by re-estimating equation (1), while controlling for each of our three measures of trust. The estimates are reported in appendix table A7. Controlling for the three trust measures has little impact on the estimated Kuba effect. Overall, the evidence suggests that the Kuba effect we estimate is not due to a greater distrust in our research team among Kuba descendants. ${ }^{42}$

\section{b. Altruism towards others}

A plausible alternative explanation for our findings is that historical state formation did not affect individual rule-following but instead impacted altruism. If the Kuba were less altruistic towards the recipients in the RAG, then this, rather than rule-following, could explain why they are more likely to cheat. To check that altruism is not confounding our interpretation of behavior

\footnotetext{
${ }^{42}$ For the version of the RAG in which the other party is the provincial government, participants' confidence in the provincial government may be an important determinant of the amount allocated to the government. If a participant has little confidence in the government he or she may be less likely to allocate the 'correct' amount to the government. As we show in section $A_{7}$ in the appendix, this mechanism does not explain the difference between the behavior of Kuba and non-Kuba in the version of the RAG where player 2 is the provincial government.
} 
Table 11: Differences in trust of our research team.

\begin{tabular}{|c|c|c|c|}
\hline & \multicolumn{3}{|c|}{ Trust: 1 not at all, 2 not very much, 3 somewhat, 4 completely } \\
\hline & $\begin{array}{l}\text { International } \\
\text { organizations }\end{array}$ & Other nationalities & Universities \\
\hline & $(1)$ & $(2)$ & $(3)$ \\
\hline & \multicolumn{3}{|c|}{ Panel A. Full sample } \\
\hline \multirow[t]{2}{*}{ Kuba ethnicity indicator } & -0.10 & -0.05 & 0.01 \\
\hline & $(0.12)$ & $(0.11)$ & $(0.11)$ \\
\hline Observations & 499 & 499 & 499 \\
\hline Mean dep var & 2.85 & 2.86 & 3.07 \\
\hline \multirow[t]{2}{*}{ R squared } & 0.07 & 0.01 & 0.11 \\
\hline & \multicolumn{3}{|c|}{ Panel B. Central Kuba \& Lele } \\
\hline \multirow[t]{2}{*}{ Kuba ethnicity indicator } & -0.02 & -0.24 & -0.13 \\
\hline & $(0.20)$ & $(0.17)$ & $(0.15)$ \\
\hline Observations & 105 & 105 & 105 \\
\hline Mean dep var & 2.87 & 2.88 & 3.27 \\
\hline \multirow[t]{2}{*}{ R squared } & 0.11 & 0.02 & 0.16 \\
\hline & \multicolumn{3}{|c|}{ Panel C. Bushong \& Lele } \\
\hline \multirow[t]{2}{*}{ Kuba ethnicity indicator } & -0.04 & -0.20 & -0.04 \\
\hline & $(0.23)$ & $(0.19)$ & $(0.16)$ \\
\hline Observations & 82 & 82 & 82 \\
\hline Mean dep var & 2.93 & 2.91 & 3.35 \\
\hline$R$-squared & 0.09 & 0.02 & 0.17 \\
\hline \multicolumn{4}{|c|}{$\begin{array}{l}\text { Notes: The table reports OLS estimates of equation (1) with self-reported measures of trust as outcome } \\
\text { variables. The dependent variable is measured on a } 1,2,3,4 \text { scale and is increasing in trust. The } \\
\text { responses are: (1) not at all, (2) not very much, (3) somewhat, (4) completely. "Kuba ethnicity } \\
\text { indicator" is a variable that equals one if the individual's self reported tribe is Kuba. All regressions } \\
\text { control for a gender indicator, age, age squared, and a survey year fixed effect. *, **, and }{ }^{* * *} \text { indicate } \\
\text { significance at the } 10,5 \text {, and } 1 \% \text { levels. }\end{array}$} \\
\hline
\end{tabular}

in the RAG, we also had participants play the dictator game (DG). In the DG, participants divide 1,OoocF between themselves and a second player. The division was done in the privacy of a tent and was made by placing the money for the other party in an envelope, sealing it, and then placing it in a bag outside the tent. Each participant played four rounds of the DG, in each round dividing $1,000 \mathrm{CF}$ between themselves and another anonymous individual, either (i) someone from Kananga, (ii) someone from the same ethnic group in Kananga, (iii) someone from a different ethnic group in Kananga, or (iv) the provincial government.

We re-estimate equation (1) with the amount given to the other player in the DG as the dependent variable. The estimates are reported in table 12. Columns 1-4 report estimates for 
Table 12: Differences in altruism.

\begin{tabular}{|c|c|c|c|c|c|}
\hline & \multicolumn{5}{|c|}{ Amount given to the other party (of $1000 \mathrm{CF}$ ) in the DG: } \\
\hline & $\begin{array}{l}\text { Citizen of } \\
\text { Kananga }\end{array}$ & $\begin{array}{c}\text { Coethnic citizen } \\
\text { of Kananga }\end{array}$ & $\begin{array}{c}\text { Non-coethnic } \\
\text { citizen of } \\
\text { Kananga }\end{array}$ & $\begin{array}{c}\text { Provincial } \\
\text { Government }\end{array}$ & Average \\
\hline & $(1)$ & $(2)$ & $(3)$ & $(4)$ & $(5)$ \\
\hline & \multicolumn{5}{|c|}{ Panel A. Full sample } \\
\hline \multirow[t]{2}{*}{ Kuba Ethnicity Indicator } & -3.80 & -12.66 & -14.09 & -13.24 & -12.46 \\
\hline & $(24.95)$ & $(22.37)$ & $(23.74)$ & $(27.43)$ & $(21.43)$ \\
\hline Observations & 499 & 499 & 499 & 465 & 465 \\
\hline \multirow[t]{2}{*}{ R squared } & 0.01 & 0.01 & 0.01 & 0.01 & 0.01 \\
\hline & \multicolumn{5}{|c|}{ Panel B. Central Kuba \& Lele } \\
\hline \multirow[t]{2}{*}{ Kuba Ethnicity Indicator } & 13.59 & -15.28 & -26.28 & -3.45 & -0.86 \\
\hline & $(41.76)$ & $(38.52)$ & (43.38) & (39.13) & $(36.74)$ \\
\hline Observations & 105 & 105 & 105 & 93 & 93 \\
\hline \multirow[t]{2}{*}{ R squared } & 0.01 & 0.07 & 0.06 & 0.01 & 0.03 \\
\hline & \multicolumn{5}{|c|}{ Panel C. Bushong \& Lele } \\
\hline \multirow[t]{2}{*}{ Kuba Ethnicity Indicator } & 17.64 & -28.72 & -45.81 & -27.84 & -8.69 \\
\hline & $(45.10)$ & $(41.38)$ & $(48.67)$ & $(41.77)$ & $(39.74)$ \\
\hline Observations & 82 & 82 & 82 & 71 & 71 \\
\hline$R$-squared & 0.01 & 0.09 & 0.07 & 0.02 & 0.02 \\
\hline
\end{tabular}

each of the four versions of the DG. ${ }^{43}$ In column 5 , we report estimates using the average amount given in the four games as the dependent variable. The estimates show that there is no statistically significant difference between the measures of altruism for Kuba and non-Kuba descendants. This suggests that the differences in cheating and stealing we observe are not due to underlying differences in altruism towards the other player. 44

\section{Conclusions}

We have investigated the impact of living under a centralized state on internal norms of rulefollowing. Though this relationship is the subject of numerous famous hypotheses in social science, to our knowledge it has never been studied empirically before. Modern states created

\footnotetext{
${ }^{43}$ We have fewer observations for the DG with the provincial government. This is because in 2013 we originally implemented only three versions of the dictator game. The version with the provincial government was implemented in 2014. Therefore, some individuals from the 2013 sample could not be located again in 2014.

${ }^{44}$ We also find that our baseline RAG results are robust to controlling for altruism towards player 2 as measured by play in the DG. See appendix table A8.
} 
monopolies of violence, bureaucracies, fiscal structures, and legal institutions. But, do they also create a different sort of person? Elias (1994), Weber (1976), and Foucault (1995) argued yes, and, in particular, that they create a population that is intrinsically motivated to obey rules. Studying such an issue is complicated because culture and institutions are endogenous to each other, and also jointly determined, making it difficult to identify the causal impact of state formation on this cultural characteristic.

We explored a unique historical natural experiment of state formation in a region that today lies within the Democratic Republic of the Congo: that of the Kuba Kingdom in the early 17th century. The Kuba Kingdom, which shares many of the features of modern states, arose idiosyncratically due to an institutional innovator named Shyaam, and its boundaries were determined by the local system of rivers in the area. The historical episode is attractive from an empirical point of view because it took place in an region inhabited by a population that was ex ante culturally homogeneous, some of whom, specifically the Lele, did not end up within the Kuba state.

Using two experiment-based measures of rule-following - the resource allocation game (RAG) and the ultimatum game with the potential for theft (UG) - and examining three samples motivated by the historical natural experiment, we found a robust negative effect of the Kuba Kingdom on norms of rule-following and against stealing. That is, Kuba descendants are less likely to follow rules and more likely to steal. In the RAG, Kuba descendants allocated significantly less to the other party than non-Kuba descendants. In addition, Kuba descendants were more likely to steal money when participating in a version of the ultimatum game in which they physically handled the money when proposing their division as player 1 .

Examining potential confounders, we showed that these differences are not due to differential selection of migrants to Kananga, the location of the study, or to geographical differences in the regions historically inhabited by Kuba and non-Kuba ancestors. We then examined a host of alternative channels. We examined whether our findings are due to differences in income, altruism, or trust of our research team. We also examined whether the Kuba were differentially impacted by colonial rule or the Mobutu regime. We found that none of these alternative channels explains the lower incidence of rule-following among the Kuba.

Overall, our findings provide evidence that institutions can crowd out intrinsic motivations for following the rules. More broadly, they raise doubts about the hypotheses proposed by Elias, Weber, and Foucault. While these studies inferred individuals' respect for rules from their actions, 
our study used direct experimental measures among a population removed from the direct effects of the institutional environment.

In an observational study of the Kuba Kingdom, one would be tempted to arrive at the same conclusion as Elias, Weber, and Foucault. The Kuba Kingdom had less conflict and was more prosperous than the neighboring Lele. However, this outcome reflects the direct effect of Kuba institutions, not necessarily the population's underlying cultural proclivities. Our findings therefore suggest caution in interpreting observational accounts of the co-evolution of institutions and culture. Their joint determination likely confound such analyses. We feel that our natural experiment, combined with our lab-in-the-field methodology generates variation that is better suited for examining the long-term impacts of institutions on culture.

\section{References}

Acemoglu, Daron and James A. Robinson, Why Nations Fail?, New York: Crown Publishers, 2012.

_, Simon Johnson, and James A. Robinson, "The Colonial Origins of Comparative Development: An Empirical Investigation," American Economic Review, 2001, 91, 1369-1401.

Alesina, Alberto, Paola Giuliano, and Nathan Nunn, "On the Origins of Gender Roles: Women and the Plough," Quarterly Journal of Economics, 2013, 128 (2), 469-530.

Algan, Yann and Pierre Cahuc, "Inherited Trust and Growth," American Economic Review, 2010, 100 (5), 2060-2092.

Anderson, Benedict, Imagined Communities: Reflections on the Origin and Spread of Nationalism, London: Verso, 2006.

Banaji, Mahzarin R. and Anthony G. Greenwald, Blindspot: Hidden Biases of Good People, New York: Delacorte Press, 2013.

Bateman, Charles S. L., First Ascent of the Kasai, London: George Philip and Son, 1889.

Becker, Sasha O., Katrin Boeckh, Christa Hainz, and Ludger Woessmann, "The Empire is Dead, Long Live the Empire! Long-Run Persistence of Trust and Corruption in the Bureaucracy," 2015. Economic Journal, forthcoming.

Benabou, Roland and Jean Tirole, "Intrinsic and Extrinsic Motivation," Review of Economic Studies, 2003, 70 (3), 489-520.

Besley, Timothy and Torsten Persson, Pillars of Prosperity: The Political Economics of Development Clusters, Princeton: Princeton University Press, 2011.

Bluemke, Matthias and Malte Friese, "Reliability and Validity of the Single-Target IAT (STIAT): Assessing Automatic Affect Toward Multiple Attitude Objects," European Journal of Social Psychology, 2008, 38, 977-997. 
Bowles, Samuel and Sandra Polania-Reyes, "Economic Incentives and Social Preference: Substitutes or Complements?," Journal of Economic Literature, 2012, 50 (2), 368-425.

Bustin, Edouard, Lunda Under Belgian Rule, Cambridge: Harvard University Press, 1975.

Callaghy, Thomas M., The State-Society Struggle: Zaire in Comparative Perspective, New York: Columbia University Press, 1984.

Cassar, Alessandra, Giovanna d'Adda, and Pauline Grosjean, "Institutional Quality, Culture, and Norms of Cooperation: Evidence from Behavioral Field Experiments," Journal of Law and Economics, 2014, 57 (3), 821-863.

de Heusch, Luc, The Drunken King, or, The Origin of the State, Bloomington: Indiana University Press, 1982.

Deci, Edward L., Richard Koestner, and Richard M. Ryan, "A Meta-Analytic Review of Experiments Examining the Effects of Extrinsic Rewards on Intrinsic Motivation," Psychological Motivation, 1999, 125 (6), 627-668.

Dedeken, Noël C., Chimères Baluba: Le Sud-Kasä̈, 1960-1962 à feu et à sang, Brussels: Dedeken Editeur, 1978.

Dincecco, Mark, Political Transformations and Public Finances: Europe, 1650-1913, New York: Cambridge University Press, 2011.

Douglas, Mary, "Lele Economy Compared with the Bushong," in Paul Bohannan and George Dalton, eds., Markets in Africa, Evanston: Northwestern University Press, 1962.

_ , The Lele of Kasai, New York: International Affairs Institute, 1963.

Dueppen, Stephen A., Egalitarian Revolution in the Savanna: The Origins of a West African Political System, New York: Routledge, 2014.

Elias, Norbert, The Civilizing Process, Oxford: Blackwell, 1994.

Evans, Peter B. and James E. Rauch, "Bureaucratic Structure and Bureaucratic Performance in Less Developed Countries," Journal of Public Economics, 2000, 75, 49-71.

Falk, Armin and Nora Szech, "Morals and Markets," Science, 2013, 340, 707-711.

Fenske, James, "Ecology, trade, and states in pre-colonial Africa," Journal of the European Economic Association, 2014, 12 (3), 612-640.

Fernandez, Raquel and Alessandra Fogli, "Culture: An Empirical Investigation of Beliefs, Work, and Fertility," American Economic Journal: Macroeconomics, 2009, 1 (1), 146-177.

Fischbacher, Urs and Franziska Follmi-Heusi, "Lies in Disguise: An Experimental Study on Cheating," Journal of the European Economic Association, June 2013, 11 (3), 525-547.

Foucault, Michel, Discipline and Punish: The Birth of the Prison, New York: Vintage Books, 1995.

Gellner, Ernest, Nations and Nationalism, Ithaca: Cornell University Press, 2009.

Gennaioli, Nicola and Ilia Rainer, "The Modern Impact of Precolonial Centralization in Africa," Journal of Economic Growth, 2007, 12 (3), 185-234. 
Gibbon, Edward, The History of the Decline and Fall of the Roman Empire, 6 Volumes, New York: Penguin, 1996.

Gino, Freancesca and Lamar Pierce, "The Abundance Effect: Unethical Behavior in the Presence of Wealth," Organizational Behavior and Human Decision Processes, 2009, 109, 142-155.

Giuliano, Paola, "Living Arrangements in Western Europe: Does Cultural Origin Matter?," Journal of the European Economic Association, 2007, 5 (5), 927-952.

Greif, Avner, "Cultural Beliefs and the Organization of Society: A Historical and Theoretical Reflection on Collectivist and Individualist Societies," Journal of Political Economy, 1994, 102 (5), 912-950.

_ , "Self-Enforcing Political Systems and Economic Growth: Late Medieval Genoa," in Robert H. Bates, Avner Grief, Margaret Levi, Jean-Laurent Rosenthal, and Barry R. Weingast, eds., Analytic Narratives, Princeton: Princeton University Press, 1998, pp. 23-63.

Grosjean, Pauline, "The Weight of History on European Cultural Integration: A Gravity Approach," American Economic Review Papers and Proceedings, 2011, 101 (3), 504-508.

Gunthrie, Malcolm, Comparative Bantu: An Introduction to the Comparative Linguistics and Prehistory of the Bantu Languages, Farnborough: Gregg Press, 1971.

Herbst, Jeffrey I., States and Power in Africa: Comparative Lessons in Authority and Control, Princeton: Princeton University Press, 2000.

Hilton-Simpson, M. W., Land and Peoples of the Kasai, London: Constable and Company, 1911.

Hruschka, Daniel, Charles Efferson, Ting Jiang, Ashlan Falletta-Cowden, Sveinn Sigurdsson, Rita McNamara, Madeline Sands, Shirajum Munira, Edward Slingerland, and Joseph Henrich, "Impartial Institutions, Pathogen Stress and the Expanding Social Network," Human Nature, 2014, 25, 567-579.

Johnson, Noel D., "Taxes, National Identity, and Nation Building: Evidence from France," 2014. Working paper, George Mason University.

Ledeneva, Alena V., How Russia Really Works: The Informal Practices That Shaped Post-Soviet Politics and Business, Ithaca: Cornell University Press, 2006.

Lowes, Sara, Nathan Nunn, James A. Robinson, and Jonathan Weigel, "Understanding Ethnic Identity in Africa: Evidence from the Implicit Association Test (IAT)," American Economic Review Papers and Proceedings, 2015, 105 (5), 340-345.

MacIntosh, Susan K., Beyond Chiefdoms, New York: Cambridge University Press, 1988.

MacMullen, Ramsay, Corruption and the Decline of Rome, New Haven: Yale University Press, 1990.

Mamdani, Mahmood, Citizen and Subject: Contemporary Africa and the Legacy of Late Colonialism, Princeton: Princeton University Press, 1996.

Mantnieks, P., “Congo Belge [map]," 1951. Institut Cartographique.

Martens, Daisy S., "A History of European Penetration and African Reaction in the Kasai Region of Zaire, 1880-1908," 1980. Unpublished PhD Dissertation, Deparment of History, Simon Fraser University. 
McCulloch, Merran, The Southern Lunda and Related Peoples (Northern Rhodesia, Belgian Congo, Angola, London: International African Institute, 1951.

McNamara, Rita Anne, Ara Norenzayan, and Joseph Henrich, "Supernatural Punishment, In-Group Biases, and Material Insecurity: Experiments and Ethnography from Yasawa, Fiji," Religion, Brain E Behavior, 2014, p. forthcoming.

Michalopoulos, Stelios and Elias Papaioannou, "Pre-Colonial Ethnic Institutions and Contemporary African Development," Econometrica, 2013, 81 (1), 113-152.

_ and _ , "National Institutions and Subnational Development in Africa," Quarterly Journal of Economics, 2104, 129 (1), 151-213.

Monroe, Cameron J., "Power and Agency in Precolonial African States," Annual Review of Anthropology, 2013, 42, 17-35.

- and Akinwumi Ogundiran, Power and Landscape in Atlantic West Africa, New York: Cambridge University Press, 2012.

North, Douglas C. and Robert Paul Thomas, The Rise of the Western World: A New Economic History, Cambridge: Cambridge University Press, 1973.

Nunn, Nathan, "Religious Conversion in Colonial Africa," American Economic Review Papers and Proceedings, 2010, 100 (2), 147-152.

Osafo-Kwaako, Philip and James A. Robinson, "Political Centralization in Pre-Colonial Africa," Journal of Comparative Economics, 2013, 41 (1), 534-564.

Peysakhovich, Alexander and David G. Rand, "Habits of Virtue: Creating Norms of Cooperation and Defection in the Laboratory," Management Science, 2015, p. forthcoming.

Piff, Paul K., Daniel M. Stancato, Stephane Cote, Rodolfo Mendoza-Denton, and Dacher Keltner, "Higher Social Class Predicts Increased Unethical Behavior," Proceedings of the National Academic of Sciences, 2012, 109 (11), 4086-4091.

Pruitt, William F., "An Independent People: A History of the Sala Mpasu of Zaire and their Neighbors," 1973. Unpublished PhD Dissertation, Department of History, Northwestern University.

Reefe, Thomas. Q., The Rainbow and the Kings: A History of the Luba Empire to 1891, Berkeley: University of California Press, 1981.

Sahlins, Marhall, "The Stranger King," Indonesia and the Malay World, 2008, 36 (105), 177-199.

Sheppard, William H., Presbyterian Pioneers in Congo, Richmond, VA: Presbyterian Committee of Publication, 1917.

Tabellini, Guido, "Presidential Address: Institutions and Culture," Journal of the European Economic Association, 2008, 6 (2-3), 255-294.

_ , "The Scope of Cooperation: Values and Incentives," Quarterly Journal of Economics, 2008, 123 (3), 905-950.

_ , "Culture and Institutions: Economic Development in the Regions of Europe," Journal of the European Economic Association, 2010, 8 (4), 677-716. 
Thesiger, Wilfred Gilbert, The Enslavement and Destruction of the Bakuba: By the "Kasai Trust," in which the Belgian Government Holds Half the Stock, and Whose Directorate it Controls, London: Congo Reform Association, 1909.

Torday, Emil, On the Trail of the Bushongo, London: Seeley, Service \& Company Limited, 1925.

- and T.A. Joyce, Notes Ethnographiques sur les Peuples Communément Appelés Bakuba, ainsi que sure les Peuplades Apparentées: Les Bushongo, Bruxelles: Ministère des Colonies, 1910.

_ and _, Notes Ethnographiques sur les Populations Habitant les Bassins du Kasai et du Kwango Oriental: I. Peuplades de la Forêt. II. Peuplades des Prairies, Bruxelles: Musée Royal de l'Afrique Centrale, 1922.

Turner, Thomas and Crawford Young, The Rise and Decline of the Zairian State, Madison: University of Wisconsin Press, 1985.

Van Reybrouck, David, Congo: The Epic History of a People, New York: Harper Collins, 2015.

Vansina, Jan, "Geschiedenis van de Kuba: van Ongeveer 1500 tot 1904," 1963. Tervuren, Musée Royal de l'Afrique Centrale.

_- "Le Royaume Kuba," 1964. Musée Royal de L'Afrique Centrale, Tervuren, Belgique Annales, Serie In-8, Sciences Humaines, no. 49.

_ , Introduction à l'ethnographie du Congo, Kinshasa: Université Lovanium, 1966.

_ , Kingdoms of the Savanna, Madison: University of Wisconsin Press, 1966.

_, "A Traditional Legal System: The Kuba," in Yehudi A. Cohen, ed., Man in Adaption: The Institutional Framework, Chicago: Aldine-Atherton, 1971, pp. 135-148.

- , The Children of Woot: A History of the Kuba Peoples, Madison: University of Wisconsin Press, 1978.

_ , Paths in the Rainforest, Madison: University of Wisconsin Press, 1990.

-, Being Colonized: The Kuba Experience in Rural Congo, 1880-1960, Madison: University of Wisconsin Press, 2010.

Verner, Samuel, Pioneering in Central Africa, Richmond: Presbyterian Committee of Publication, 1903.

von Wissmann, Hermann, My Second Journey Through Equatorial Africa from the Congo to the Zambezi in the Years 1886 and 1887, London: Chatto and Windus, 1891.

Weber, Eugene, Peasants into Frenchmen: The Modernization of Rural France, 1870-1914, Stanford: Stanford University Press, 1976.

Wharton, Conway T., The Leopart Hunts Alone, New York: Fleming H. Revell Company, 1927.

Yoder, John C., The Kanyok of Zaire: An Institutional and Ideological History to 1895, New York: Cambridge University Press, 1992. 